\title{
Iron isotope investigation of hydrothermal and sedimentary pyrite and their aqueous dissolution products
}

Amy L. Wolfe ${ }^{\mathrm{a}}$, Brian W. Stewart ${ }^{\mathrm{a}^{*}}$, Rosemary C. Capo ${ }^{\mathrm{a}}$, Ran Liu ${ }^{\mathrm{b}, \mathrm{c}}$, David A. Dzombak ${ }^{\mathrm{b}}$, Gwyneth Gordon ${ }^{\mathrm{d}}$, Ariel D. Anbar, ${ }^{\mathrm{d}, \mathrm{e}}$

${ }^{\mathrm{a}}$ Department of Geology \& Planetary Science, University of Pittsburgh, Pittsburgh, PA 15260, USA

${ }^{\mathrm{b}}$ Department of Civil \& Environmental Engineering, Carnegie Mellon University, Pittsburgh, PA 15213, USA

${ }^{c}$ Pennsylvania American Water, 852 Wesley Drive, Mechanicsburg, PA 17055, USA

${ }^{\mathrm{d}}$ School of Earth \& Space Exploration, Arizona State University, Tempe, AZ 85287, USA

${ }^{\mathrm{e}}$ Department of Chemistry \& Biochemistry, Arizona State University, Tempe, AZ 85287, USA

*Corresponding author

Email address: bstewart@ @itt.edu (B.W. Stewart) 


\section{ABSTRACT}

2 Oxidative dissolution experiments were carried out on pyrite from multiple petrogenetic

3 environments (hydrothermal, sedimentary fossil replacement, and coal-related nodules) to

4 investigate possible variations in the iron isotopic composition of pyrite and the products of

5 pyrite dissolution. The experimental materials were leached under carefully controlled abiotic

6 conditions, and a subset of leachates and starting materials from these experiments was analyzed

7 for ${ }^{56} \mathrm{Fe} /{ }^{54} \mathrm{Fe}$ by multicollector ICP-MS. Bulk pyrite $\delta^{56} \mathrm{Fe}$ values (relative to IRMM-014) ranged

8 from -0.1 to $+1.3 \%$, with hydrothermal bulk pyrite values $<+0.5 \%$ and those of coal and

9 sedimentary nodular pyrite $\geq+0.5 \%$, higher than most previously measured values for

10 Phanerozoic sedimentary pyrite. We suggest that this reflects precipitation of coal pyrite from a

11 high- $\delta^{56} \mathrm{Fe}$ continental source, such as Fe derived from dissolution of Fe(III) oxides. This could

12 allow differentiation of Fe contributed from coal- and shale-related pyrite at abandoned mine

13 drainage sites. Leachates from oxidative dissolution of the pyrite at $\mathrm{pH}=3$ yielded, with few

14 exceptions, $\delta^{56} \mathrm{Fe}$ values equal to or lower than those of the coexisting bulk pyrite, by up to about

15 1\%o. These shifts are consistent in direction (but not magnitude) with equilibrium isotope

16 fractionation predictions from theory, with possible second order effects from isotopic

17 heterogeneity within individual natural pyrite samples. 


\section{Introduction}

20 Iron sulfides constitute a diverse group of solid and dissolved complexes in aqueous

21 geochemical systems, and play an essential role in regulating and controlling the global

22 geochemical Fe and S cycles. Pyrite $\left(\mathrm{FeS}_{2}\right)$, the most common sulfide mineral on the Earth's

23 surface (Vaughan, 2006), is found in a wide variety of geologic environments. It can form under

24 high temperature conditions, including contact metamorphism and hydrothermal fluid

25 circulation, and in low temperature $\left(<100^{\circ} \mathrm{C}\right)$ sedimentary environments. In the latter case,

26 pyrite is considered a redox buffer in anoxic conditions, and its presence is a strong indicator of

27 reducing conditions (Descostes et al., 2004). Metastable Fe sulfide phases have important roles

28 in biogeochemical processes (Rickard and Luther, 2007). In addition, oxidative dissolution of Fe

29 sulfide minerals is the cause of acid mine drainage (AMD), a serious water quality problem in

30 coal and metal mining regions.

31 Experimental studies of pyrite dissolution, conducted primarily on hydrothermal pyrite, have

32 shown that the rate of pyrite oxidation is dependent on factors such as $\mathrm{pH}$, dissolved oxygen,

33 ferric Fe concentrations and the presence of Fe- or S-oxidizing bacteria (e.g., Singer and Stumm,

34 1970; McKibben and Barnes, 1986; Moses et al., 1987; Moses and Herman, 1991; Williamson

35 and Rimstidt, 1994; Holmes and Crundwell, 2000; Weber et al., 2004; Paschka and Dzombak,

36 2004). However, even when these variables are controlled, there can still be significant

37 differences in experimental dissolution rates when pyrite samples from different environments

38 are used as starting material (Liu et al., 2008b).

39 In this study, Fe isotopes were measured during oxidative dissolution experiments using

40 different pyrite types (hydrothermal, fossil replacement, and sedimentary) as a new approach to

41 track pyrite dissolution, especially under AMD conditions, as well as to identify possible isotope

42 variations due to pyrite petrogenesis. Iron isotopes are fractionated during biological and abiotic 
43 redox changes, organic complexation, bacterial interactions, and surface adsorption and mineral

44 precipitation reactions (Beard and Johnson, 1999; Johnson and Beard, 1999; Anbar et al., 2000;

45 Bullen et al., 2001a; Icopini et al., 2004; Borrok et al., 2009; Czaja et al., 2010; Morgan et al.,

46 2010; Guilbaud et al., 2011). Iron isotopes have been used as a tool to examine sources and

47 mechanisms controlling Fe cycling in freshwater environments and soils (Fantle and DePaolo,

48 2004; Emmanuel et al., 2005; Ingri et al., 2006; Bergquist and Boyle, 2006; Borrok et al., 2009),

49 and during oxidative weathering of sulfide rich rocks and minerals (Herbert and Schippers, 2008;

50 Borrok et al., 2009; Fernandez and Borrok, 2009). Theoretical estimates using Mössbauer and

51 vibrational spectroscopy predict significant fractionation effects between pyrite and ferrous Fe

52 (Polyakov and Mineev, 2000), but interpretations remain somewhat unclear given the lack of

53 experimental determination of $\mathrm{Fe}$ fractionation factors associated with pyrite formation and

54 dissolution (Severmann et al., 2006). This is an investigation of Fe isotope fractionation

55 occurring during pyrite oxidation under highly controlled $\mathrm{pH}-\mathrm{pO}_{2}$ conditions.

\section{2. Methods}

\subsection{Samples and characterization}

59 The eight pyrite samples used in this study, three hydrothermal and five sedimentary, were

60 the same as those used in the oxidative dissolution experiments reported by Liu et al. (2008b),

61 and their morphology and geological origins are provided in Table 1. The hydrothermal pyrite

62 samples are nodular single crystals, while the sedimentary pyrite samples include massive pyrite

63 found within shale (pyrite sun; SED-1), a fossil replacement (SED-2), and nodular pyrite

64 collected from coal seams (SED-COAL-1, SED-COAL-2, SED-COAL-3).

65 Pyrite samples were crushed, milled, and wet sieved using a procedure developed by Wolfe

66 et al. (2007) to obtain $45-75 \mu \mathrm{m}$ fractions for use in dissolution experiments. The specific 
67 surface area of each sample was measured by the nitrogen adsorption multipoint BET method

68 with a Quantosorb instrument (ISO, 2010); accuracy of the instrument was verified by

69 measurements on alumina and black carbon standards of known surface area. Particle surfaces

70 were examined pre- and post- cleaning using a Philips XL-30 FEG field emission scanning

71 electron microscope. The crushed and sieved samples were split for geochemical/isotopic

72 analysis and dissolution experiments. The geochemical splits were dissolved in warm nitric acid,

73 and aliquots were taken for trace element and Fe isotope analyses. The remainder of the 45-75

74 $\mu \mathrm{m}$ material was used for abiotic oxidative dissolution experiments, as reported by Liu et al.

75 (2008b). Three of the samples (HY-3, SED-2, and SED-COAL-1) were also used for

76 electrochemical dissolution experiments (Liu et al., 2008a; 2009).

\subsection{Dissolution experiment setup}

For each pyrite sample, dissolution rates were determined under oxic conditions in a batch

81 the experiments, pyrite samples were treated to remove any surface Fe oxides or Fe sulfates that

82 could have been produced when the samples were exposed to the atmosphere. This procedure, a

83 modified version of a method used by Paschka and Dzombak (2004), involved boiling 7-8 g of

84 pyrite in $50 \mathrm{ml}$ concentrated hydrochloric acid $(\mathrm{HCl})$ for approximately 10 minutes. The sample

85 was rinsed with boiling concentrated $\mathrm{HCl}$ at least twice, then rinsed with $25 \mathrm{ml}$ deionized water,

86 followed by a boiling acetone rinse using a vacuum filter. The acetone rinse was repeated a

87 minimum of three times. The sample was dried in an oven at $115^{\circ} \mathrm{C}$ for about 10 minutes and

88 stored in a desiccator. Samples were used within two hours of preparation. Specific surface area

89 measurements were conducted prior to the cleaning procedure. 
A $5.355 \pm 0.005 \mathrm{~g}$ aliquot of the cleaned pyrite was added to $1.5 \mathrm{~L}$ of deionized water in a

91 stirred, jacketed glass vessel with a lid having sealed ports for insertion of reagents and

92 withdrawal of samples from the reactor; the initial ionic strength was adjusted by addition of

$930.01 \mathrm{M}$ sodium chloride $(\mathrm{NaCl})$. During the experiments, the reactor was covered with

94 aluminum foil to exclude light, and the temperature was kept at $25 \pm 0.01^{\circ} \mathrm{C}$. A constant $\mathrm{pH}$ of

$953.00 \pm 0.05$, to mimic the AMD environment and inhibit oxidation and precipitation of the

96 released $\mathrm{Fe}$, was maintained by the addition of $\mathrm{HCl}$ or sodium hydroxide $(\mathrm{NaOH}) \mathrm{via}$ acid/base

97 pumps and a pH-stat. The concentration of dissolved oxygen was maintained in the range of 9-

$9812 \mathrm{ppm}$ (corresponding to freshwater air saturation concentrations at temperatures $<25^{\circ} \mathrm{C}$; Colt,

99 2012) by controlling the oxygen partial pressure in the reactor headspace (Paschka and

100 Dzombak, 2004; Liu et al., 2008b).

101 Concentrations of Fe and $\mathrm{S}$ were measured in the leachate to monitor pyrite dissolution. Five

102 milliliters of sample were collected periodically over a 24 hour time period, and then filtered

103 through a $0.45 \mu \mathrm{m}$ disposable filter into a $20 \mathrm{ml}$ polyethylene scintillation vial containing $5 \mathrm{ml}$

$10410 \%$ nitric acid $\left(\mathrm{HNO}_{3}\right)$ for $\mathrm{Fe}$ and $\mathrm{S}$ elemental analyses. A three-way stopcock was used for

105 sampling to ensure the headspace of the reactor would remain unaffected by the outside

106 environment during the experiments. Additional details are provided by Liu et al. (2008b).

\subsection{Elemental analyses}

109 Total dissolved iron in the leachates was measured using atomic absorption spectroscopy

110 (AA); flame AA was used for samples containing iron concentrations greater than the detection

111 limit of $100 \mu \mathrm{g} / \mathrm{L}$ and graphite furnace AA was used for samples with lower concentrations of

112 iron (detection limit $=1.0 \mu \mathrm{g} / \mathrm{L}$; Liu, 2007). Dissolved sulfur concentrations within the

113 experimental leachates and $\mathrm{S}$ and Fe concentrations in the bulk pyrite digestions were measured 
114 on a SpectroFlame End-On Plasma inductively coupled plasma atomic emission spectrometer 115 (ICP-AES) using EPA Method 6010C (US EPA, 2007). Accuracy of measurements was within $116 \pm 5 \%$ of true values. Instrument calibration was carried out using standard solutions (5\% nitric

117 acid matrix) containing different concentrations of Fe and S. All the aqueous samples were 118 preserved in a 5\% nitric acid matrix before ICP-AES and AA measurements. In the dissolved 119 bulk pyrite solutions, abundances of more than 40 trace elements were analyzed by inductively 120 coupled plasma mass spectrometry (ICP-MS) by contract with Activation Laboratories Ltd.,

121 Ontario, Canada.

\subsection{Isotopic analyses}

124 Aliquots of leachate samples from each pyrite dissolution experiment were collected for Fe 125 isotope analysis at 1,8 and 24 hours from the start of the experiment, with the exception of 126 sample HY-3, in which the first sample was collected at 6 hours. The isotopic composition of the

127 leachate collected at each time interval $(1,8$, and $24 \mathrm{hr})$ is cumulative (versus cyclic, e.g., 128 Fernandez and Borrok, 2009) and reflects the average of all isotopic changes prior to each 129 sampling interval. Aliquots of the bulk dissolved samples (HY-1, HY-2, SED-1, SED-COAL-1, 130 SED-COAL-3) were quantitatively separated for Fe isotope analysis. Iron separations for all 131 samples were conducted in a laminar flow clean hood based on a procedure modified after 132 Bullen et al. (2001b). Aliquots containing at least $20 \mu \mathrm{g}$ of Fe were evaporated to dryness in 133 Teflon containers and redissolved in $5 \mathrm{~mL}$ of $6.0 \mathrm{~N} \mathrm{HCl}$ for anion exchange chromatography. 134 The solution was loaded onto an anion exchange column (BioRad AG1X8) previously cleaned 135 with alternating $1.0 \mathrm{~N} \mathrm{HCl}$ and ultrapure water. The resin was then conditioned using $6 \mathrm{ml}$ of 6.0 $136 \mathrm{~N} \mathrm{HCl}$. After the sample solution had been loaded on the resin, the matrix was removed in $11 \mathrm{ml}$ 137 of $6.0 \mathrm{~N} \mathrm{HCl}$ and $1 \mathrm{ml}$ of ultrapure water. The Fe was eluted with alternating $1 \mathrm{ml}$ aliquots of 1.0 
$\mathrm{N} \mathrm{HCl}$ and ultrapure water, evaporated to dryness, and then the column separation procedure was

139 repeated. After passing through the column a second time, the sample was evaporated to dryness

140 and redissolved in $2 \% \mathrm{HNO}_{3}$ for MC-ICP-MS analysis. Columns were calibrated throughout the

141 procedure using matrix-matched samples to ensure quantitative yields within error of $\mathrm{Fe}$

142 concentration measurements.

143 Isotopic ratios were measured at Arizona State University using a Thermo Neptune multiple

144 collector inductively coupled plasma mass spectrometer (MC-ICP-MS). Solutions were

145 analyzed at a concentration of 2-3 ppm Fe with a NIST Cu spike added to correct for

146 instrumental mass bias (Maréchal et al., 1999; Arnold et al., 2004). Sample solution duplicates

147 and one procedural blank were analyzed for each petrogenetic group of samples. All reported Fe

148 isotopes values reflect the average of replicate measurements. The ratios ${ }^{56} \mathrm{Fe} /{ }^{54} \mathrm{Fe}$ and ${ }^{57} \mathrm{Fe} /{ }^{54} \mathrm{Fe}$

149 were measured simultaneously; as a quality control measure, analyses that did not demonstrate

150 the expected mass-dependent relationship within $0.03 \%$ per amu between these ratios were

151 rejected and rerun. Samples were run with an in-house ICP Fe solution as the bracketing

152 standard and corrected to the international IRMM-014 Fe standard. IRMM-014 and TAG-01 (an

153 in-house marine sediment digest) were run in parallel with the samples, and gave values accurate

154 to within $0.05 \%$ from the long-term laboratory average. In addition, two standards (Grav-ICPB

155 and GrvIRMM) had been created by addition of a calibrated ${ }^{54} \mathrm{Fe}$ isotope spike to a known

$1561.05 \%$ from their respective standards. Both of these "gravimetric" standards gave values within

$157 \quad 0.05 \%$ from their independently known values. The measured $\delta^{56} \mathrm{Fe}$ values were compared with

158 and without normalization to a constant NIST Cu ratio, and there was always less than a $0.13 \%$

159 difference between the two methods of calculation, indicating that the samples had low residual

160 matrix and that the instrumental mass bias was smoothly varying during the analyses. Isotopic

161 ratios are expressed in standard delta notation (in units of per mil, \%o) relative to IRMM-014: 


$$
\delta^{56} \mathrm{Fe}=\left[\left(\frac{{ }^{56} \mathrm{Fe}^{54} \mathrm{Fe}_{\text {sample }}}{{ }^{56} \mathrm{Fe} /{ }^{54} \mathrm{Fe}_{\text {IRMM }}}\right)-1\right] \times 1000
$$

164 The measurement uncertainty $(2 \sigma)$ was less than $\pm 0.1 \%$ of the reported $\delta^{56} \mathrm{Fe}$ value.

\section{3. Results}

\section{3.1. Bulk pyrite sample characterization}

168 X-ray diffraction analyses (Philips XRD PW3710) indicated that all samples consisted 169 primarily of pyrite, although SED-COAL-3 contained minor $(\leq 10 \%)$ quartz. Chemical analyses

170 of $\mathrm{Fe}$ and $\mathrm{S}$ concentrations in the bulk pyrite samples confirmed stoichiometric $\mathrm{FeS}_{2}$ in the 171 starting material (i.e., S:Fe molar ratio = 2; Table 1). Chemical analyses of more than 40 trace

172 elements, including the rare earth elements (REE), showed that hydrothermal pyrite samples

173 generally contained more $\mathrm{Co}, \mathrm{Bi}$ and $\mathrm{Te}$, and less $\mathrm{Tl}, \mathrm{Ba}, \mathrm{Rb}$ and $\mathrm{Sr}$ than the sedimentary pyrite

174 samples (Table 2). Sedimentary samples associated with coal (SED-COAL-1, -2, and -3)

175 contained more Hg compared to the other sedimentary (SED-1 and -2) and hydrothermal pyrite 176 samples.

177 REE concentrations can provide information about the source of solutes in solutions 178 associated with pyrite formation. Because the REE do not readily substitute for major 179 constituents in the pyrite structure, they are thought to be held in fluid inclusions or crystal 180 defects (Zhao and Jiang, 2007), and the patterns reflect those of the mineralizing fluids (Mills 181 and Elderfield, 1995; Song et al., 1997). The REE concentrations in most of the pyrite samples 182 analyzed here fell below chondritic values (Anders and Grevasse, 1989), with the exceptions of 183 SED-COAL-2 and HY-3 (Table 2, Fig. 1). The sedimentary pyrite samples generally showed an 184 enrichment in light REE (i.e., La to Sm) similar to that of the North American Shale Composite 
185 (NASC; Gromet et al., 1984), but at significantly lower concentrations. The patterns (but not 186 concentrations) were also similar to those of Pennsylvanian coals analyzed by Schatzel and 187 Stewart (2003). While the lower concentrations in the pyrite from this study were most likely 188 due to exclusion of REE from the pyrite crystal structure, the marked light REE enrichment of 189 the sedimentary pyrite samples suggests derivation of the REE from a shale-like source (i.e., the 190 shale or coal host rock; McLennan, 1989). Two of the hydrothermal pyrite samples (HY-2 and 191 HY-3) exhibited a distinctive middle-REE enrichment superimposed on an overall flat pattern

192 (Fig. 1). This is consistent with precipitation from a hydrothermal fluid which may have 193 interacted with multiple rock types before and during pyrite crystallization (Fralick et al., 1989; 194 Mills and Elderfield, 1995; Chen et al., 1998; Zhao and Jiang, 2007).

\subsection{Dissolution experiments: Aqueous chemistry vs. time}

The dissolved iron and sulfur concentrations in leachate collected during each sampling interval $(1,8$, and 24 hours) over the course of the pyrite dissolution experiments, and corresponding S:Fe ratios, are shown in Table 3. Experimental results showed that pyrites from 200 different geologic environments exhibited distinctive dissolution behavior (Liu et al., 2008b).

201 Based on the total dissolved Fe released over the experimental period ( $24 \mathrm{hr})$, the extent of 202 dissolution was similar for the hydrothermal and the two sedimentary pyrite samples (SED-1, 203 SED-2); however, coal pyrite samples dissolved much faster than the other pyrite samples, with 204 SED-COAL-3 > SED-COAL-1 > SED-COAL-2 > HY-1 > SED-1 > SED-2 > HY-3 > HY-2. 205 When normalized for surface area, these differences are reduced, but not completely eliminated 206 (Liu et al., 2008b). The fraction of total iron released from each sample over the experimental 207 period was $<0.13 \%$ (range $=0.06-0.13 \%$ ) for hydrothermal and sedimentary pyrite samples, 208 and ranged between $0.5-1.1 \%$ for the coal pyrite samples. Dissolved S concentrations also 

increased over time for all pyrite samples (Table 3) and the total fraction of sulfur released into

210 solution from each sample was similar to the trends observed in total Fe calculations $(<0.10 \%$ for

211 hydrothermal and sedimentary pyrite and ranged between $0.5-0.9 \%$ for the coal pyrite 212 samples).

213 Aqueous speciation for dissolved iron and sulfur, in contact with solid (i.e., undissolved) 214 pyrite, was calculated using Visual MINTEQ (summarized in Table 4 and Figure2; Gustafsson, 215 2012), using measured $\mathrm{pH}$, oxidation-redox potential, dissolved oxygen, sulfur, and iron 216 concentrations, and the (calculated) amount of pyrite remaining in solution at each sampled time 217 interval (i.e., 1, 8, and $24 \mathrm{hr}$; Liu, 2007). Results indicated that, over the duration of the 218 experiment, iron existed predominantly as $\mathrm{Fe}^{2+}(\mathrm{aq})$, with minor $(<0.5 \%) \mathrm{FeSO}_{4}(\mathrm{aq})$, and $\mathrm{FeCl}^{+}$; 219 these results are consistent with previous experimental work with hydrothermal pyrite under the 220 same conditions in which no ferric Fe was detected at any time during the experiment (Paschka 221 and Dzombak, 2004; Liu et al., 2008b). Speciation calculations for sulfur indicated that $\mathrm{SO}_{4}{ }^{-2}$ 222 was the dominant species over the 24-hour experimental period, with minor $(<10 \%) \mathrm{HSO}_{4}{ }^{-}$, $223 \mathrm{FeSO}_{4}(\mathrm{aq})$ and $\mathrm{NaSO}_{4}{ }^{-}$also present. These calculations support ion chromatography 224 measurements in which sulfate was the only oxidized S species detected (Paschka and Dzombak, 225 2004). Speciation calculations indicated that the solutions were saturated with respect to 226 elemental sulfur for all samples, at each sampling interval, but decreased over the experimental 227 period. $\mathrm{No}_{2} \mathrm{~S}$ (or other sulfur gas, e.g., Descostes et al., 2004) was present.

228 A solution phase molar S:Fe ratio of 2:1 would be expected from stoichiometric dissolution 229 of pyrite, from a reaction such as

$$
\mathrm{FeS}_{2}(\mathrm{~s})+3.5 \mathrm{O}_{2}+\mathrm{H}_{2} \mathrm{O} \rightarrow \mathrm{Fe}^{2+}+2 \mathrm{SO}_{4}{ }^{2-}+2 \mathrm{H}^{+}
$$


233 (McKibben and Barnes, 1986). Ratios of S to Fe in the experimental solutions (Table 3)

234 demonstrated that pyrite did not dissolve stoichiometrically, at least in the early stages of

235 dissolution. The S/Fe ratio of all samples increased over the duration of the experiment (Fig. 3),

236 with the exception of sample SED-COAL-3, where the S/Fe ratio remained approximately

237 constant at $\sim 1.7$. Liu et al. (2008b) suggested that the low initial S/Fe ratios (i.e., sulfur deficit)

238 could have resulted from a multistep reaction (after Descostes et al., 2004) involving

239 intermediate thiosulfate $\left(\mathrm{S}_{2} \mathrm{O}_{3}{ }^{2-}\right)$ and tetrathionate $\left(\mathrm{S}_{4} \mathrm{O}_{6}{ }^{2-}\right)$ ions and solid phase elemental sulfur,

240 with the overall reaction:

241

$242 \mathrm{FeS}_{2}(\mathrm{~s})+2.9 \mathrm{O}_{2}+0.6 \mathrm{H}_{2} \mathrm{O} \rightarrow \mathrm{Fe}^{2+}+0.4 \mathrm{~S}^{0}(\mathrm{~s})+1.6 \mathrm{SO}_{4}{ }^{2-}+1.2 \mathrm{H}^{+}$

244 Druschel and Borda (2006) also present possible reactions involving multiple sulfur species to 245 describe different pathways for pyrite oxidation. Liu et al. (2008b) further suggested that 246 thermodynamically allowable shifts in the stoichiometric coefficients for $\mathrm{S}^{0}(\mathrm{~s})$ and $\mathrm{SO}_{4}{ }^{2-}$ in Eq.

247 (2) could be responsible for $\mathrm{S} / \mathrm{Fe}$ ratios <1.6. They noted that the $\mathrm{S}$ :Fe ratio increased with time, 248 but did not reach the 2:1 molar ratio expected for stoichiometric dissolution. When the amounts 249 of S and Fe released during each time interval during the dissolution experiments (rather than the 250 cumulative total) are calculated (i.e., $[\mathrm{S}]_{8 \mathrm{hrs}}-[\mathrm{S}]_{1 \mathrm{hr}}$ etc.), it becomes apparent that the 251 instantaneous dissolution ratio approaches that of stoichiometric dissolution of pyrite (Fig. 4).

252 These trends provide further support that oxidation of pyrite occurred via multiple pathways over 253 the course of the experiment. 
256 Iron isotope data for bulk pyrite samples and for the aqueous leachates from the pyrite 257 dissolution experiments are presented in Table 5 and plotted in Figure 5. Bulk pyrite $\delta^{56} \mathrm{Fe}$ 258 values spanned a range from -0.1 to +1.3 . In general, hydrothermal bulk pyrite samples 259 exhibited a slightly lower $\delta^{56} \mathrm{Fe}$ value (around 0.0 ) compared to the sedimentary pyrite samples $260(+0.5$ to +1.3$)$. The $\delta^{56} \mathrm{Fe}$ values for bulk hydrothermal pyrite from this study were within the 261 previously measured range for hydrothermal pyrite (Sharma et al., 2001; Rouxel et al., 2003;

262 2004; 2008; Graham et al., 2004; Wawryk and Foden, 2015).

\subsection{Iron isotopes in leachates}

265 The Fe isotope compositions of hydrothermal and sedimentary pyrite dissolution samples 266 over the experimental reaction periods studied are presented in Table 5 and plotted against

267 sampling time in Figure 6. For those cases where data were obtained for both the bulk pyrite and 268 leachate samples, the leachates were generally lower in $\delta^{56} \mathrm{Fe}$ (i.e., lighter) than the bulk pyrite. 269 The magnitude of offset was typically $<0.5 \%$, but could be as large as $1 \%$ in some cases (Figs.

$2705, \mathbf{5}$ ), and well outside the experimental uncertainty of $\pm 0.1 \%$. In Figure 7, the $\delta^{56} \mathrm{Fe}$ values for 271 the leachates are normalized to the first leachate value and plotted against the sampling time for 272 the oxidative dissolution experiments. In the majority of cases, the leachate values remained 273 constant or decreased with increasing time of leaching. The major exception to this was

274 sedimentary pyrite sample SED-2, which showed a significant increase (0.9\%o) from 480 minutes 275 (8 hours) to 1440 minutes ( 24 hours). $\delta^{56} \mathrm{Fe}$ values from the 60 minute leachate and bulk pyrite 276 were not obtained for this sample. In addition, the coal pyrite sample SED-COAL-3 showed an 277 increase of $\sim 0.2 \%$ from 1 to 8 hours, followed by a significant drop by the 24 hour sampling 278 interval (Fig. 7). 


\section{Discussion}

\subsection{Iron isotope composition of bulk pyrite samples}

282 The rate and extent to which pyrite forms and accumulates within the environment is

283 principally controlled by the amount of organic matter, the availability of reactive Fe minerals

284 (those that react with sulfide, primarily Fe oxides; Canfield, 1989; Canfield et al., 1992) within

285 the sediment, and the availability of dissolved sulfate. These various reactions and the central

286 role of Fe in them suggest that pyrite formed in different diagenetic environments could have

287 different Fe isotope ratios.

288 Figure 8 summarizes the Fe isotopic compositions of marine pyrite samples that have been

289 measured to date. Rouxel et al. (2005) analyzed the Fe isotope composition of diagenetic pyrite

290 from marine shales and found systematic variations in the $\delta^{56} \mathrm{Fe}$ range and values over geologic

291 time, with highly negative values (some below -3.5\%) occurring mostly in the Archean (pre-2.3

$292 \mathrm{Ga})$, positive values up to +1.2 in the Paleoproterozoic (2.3-1.8 Ga), and a fairly narrow range of

293 values $(-0.5$ to +0.2$)$ from $\sim 1.5$ Ga to the present. They interpreted the pyrite as largely

294 recording the Fe isotope composition of seawater, which was controlled by precipitation of Fe

295 oxides (with high $\delta^{56} \mathrm{Fe}$ ) under varying redox conditions and seawater Fe concentrations. In

296 contrast, Archer and Vance (2006) suggested that multiple cycles of dissimilatory Fe reduction

297 (DIR) were responsible for a wide range of negative $\delta^{56} \mathrm{Fe}$ values $(-2.7$ to -0.9 ; Fig. 8) that they

298 measured within a small section of core from the Archean Belingwe sedimentary basin in

299 Zimbabwe. Johnson et al. (2008) and Czaja et al. (2010; 2012) identified biological processes as

300 responsible for the wide range of Precambrian $\delta^{56} \mathrm{Fe}$ values, including a bacterial DIR-driven

301 "shuttle" in which strongly ${ }^{56} \mathrm{Fe}$-depleted iron is captured in a sulfidic trap in the euxinic portions

302 of oceanic basins. Based on lake sediments that serve as an Archean ocean analogue, Busigny et 
304 redox boundary, probably related to photosynthesis. Meso- and Neoarchean pyrite grains

305 interpreted to be detrital yielded $\delta^{56} \mathrm{Fe}$ values ranging from -3.6 to +1.2 (Hofmann et al., 2009).

306 Nishizawa et al. (2010) analyzed numerous Precambrian sedimentary pyrite grains by laser 307 ablation, and found a wide range of $\delta^{56} \mathrm{Fe}$ values for pre-2.2 Ga sediments $(-2.9$ to +2.2$)$, while

308 0.70-0.63 Ga sediments yielded a smaller range of values (-0.2 to +0.6). Laser ablation analysis

309 of 2.7-2.5 Ga marine sediments and 3.7-3.8 Ga metasediments (Yoshiya et al., 2012; 2015)

310 yielded a wide range of values $(-4.2$ to +2.8$)$. In situ secondary ion mass spectrometry (SIMS)

311 analyses of two $2.7 \mathrm{Ga}$ pyrite nodules yielded $\delta^{56} \mathrm{Fe}$ values ranging from -2.1 to +0.7 (Marin-

312 Carbonne et al., 2014). $\delta^{56} \mathrm{Fe}$ values of pyrite from Phanerozoic and modern sediments were

313 mostly negative, in the range of -1.6 to +0.2 (Fehr et al., 2008; 2010; Duan et al., 2010).

314 However, individual SIMS spots from diagenetic pyrite grains in Holocene Baltic Sea sediments

315 yield $\delta^{56} \mathrm{Fe}$ values ranging from -3.1 to +4.1 (Virtasalo et al., 2013). Iron isotope measurements

316 of mid-ocean ridge hydrothermal sulfides, altered oceanic crust, and a continental Sb-W deposit

317 yielded a range of values from -2.1 to 0.0 (Sharma et al., 2001; Rouxel et al., 2003; 2004), and

$318 \delta^{56} \mathrm{Fe}$ values from a laser ablation study of pyrite from a porphyry $\mathrm{Cu}-\mathrm{Au}$ deposit ranged

319 from -1.7 to +1.1 (Graham et al., 2004).

320 The sedimentary and coal nodule bulk pyrite samples analyzed here, all of Paleozoic age,

321 yielded positive $\delta^{56} \mathrm{Fe}$ values that fall outside of the range of most Phanerozoic or modern

322 sedimentary pyrite samples measured to date, with the exception of the SIMS analyses of

323 Holocene Baltic Sea sediments (Virtasalo et al., 2013). The sedimentary pyrite samples studied

324 are likely to have formed in sediments of non-marine or marginal-marine origin (i.e., continental

325 margin coal-forming mires), with the possible exception of SED-2 (Table 1). In these settings,

326 the most reactive Fe fraction is fine-grained ferric oxides formed via continental weathering, 
327 while less reactive fractions include clay-bound Fe and other Fe-containing minerals (Berner, 328 1984). Other sources of Fe may include ionic form in solution, Fe as organic complexes (e.g., 329 Toner et al., 2009), and Fe released by decay of plant debris (Wiese and Fyfe, 1986). Canfield 330 (1989) determined that early pyrite forms almost exclusively from Fe oxides, with little evidence

331 for the involvement of silicate minerals. Precipitation of Fe(III) oxides enriches the oxides in

332 heavy Fe, so Fe oxides likely provided a high- $\delta^{56} \mathrm{Fe}$ pool of Fe from which the sedimentary

333 pyrite precipitated. The high $\delta^{56} \mathrm{Fe}$ of the coal-related sedimentary pyrite nodules argues against

334 a strong biological role in their formation, or fractionation effects related to partial Fe(II) $)_{\mathrm{aq}}$

335 utilization during abiotic precipitation (Guilbaud et al., 2011), as both would result in relatively

336 low $\delta^{56} \mathrm{Fe}$. Instead, these values suggest a continentally-derived heavy $\delta^{56} \mathrm{Fe}$ oxide source that

337 was almost completely transformed to pyrite.

338 The positive $\delta^{56} \mathrm{Fe}$ values measured here in coal pyrite contrast with the largely negative 339 shale pyrite values measured in most Phanerozoic marine sediments. This suggests that Fe 340 isotopes have the potential to serve as tracers to identify the source of Fe in acid mine drainage 341 situations; that is, to distinguish between pyrite in coal and pyrite from adjacent marine shale 342 units often associated with coal units. Pyrite from sample SED-2 formed as s fossil replacement 343 during or after diagenesis. This sample, as well as SED-1, was selected for practical reasons in 344 regard to the dissolution experiments, and would not necessarily represent the "typical" $\delta^{56} \mathrm{Fe}$ of 345 Phanerozoic shale pyrite.

\subsection{Iron isotope composition of pyrite leachates}

348 The Fe isotope data from the oxidative dissolution experiments indicate: (1) $\delta^{56} \mathrm{Fe}$ values of 349 the leachates were equal to or less than bulk pyrite values, where available (Fig. 5); and (2) with 350 a few exceptions, as leaching time increased, the $\delta^{56} \mathrm{Fe}$ values remained constant or decreased 
351 (Fig. 7). Fernandez and Borrok (2009) carried out leaching experiments and $\mathrm{Fe}, \mathrm{Cu}$ and $\mathrm{Zn}$ 352 isotope analyses on sulfide-rich rocks associated with hydrothermal metal deposits. These 353 samples, which were crushed and leached in bulk, included mine waste rock and altered

354 volcaniclastic bedrock containing pyrite, chalcopyrite and sphalerite. These authors observed a 355 similar trend of decreasing $\delta^{56} \mathrm{Fe}$ over time, with a drop of $\sim 1 \%$, for experiments conducted at $356 \mathrm{pH}=2$ (buffered with $\mathrm{HCl}$ ). A significant difference, however, was that the $\delta^{56} \mathrm{Fe}$ value in their 357 leachates started out higher than the bulk sample, and gradually approached the bulk sample 358 value. In the experiments reported here, most of the leachate values initially were equal to or 359 less than the bulk pyrite value (where available), and remained constant or decreased with time 360 (Figs. 6, 7). Fernandez and Borrok (2009) attributed the trend they observed to dissolution of 361 high- $\delta^{56} \mathrm{Fe} \mathrm{Fe}(\mathrm{III})$ oxides that formed in the elapsed time between when the rock was crushed 362 and the experiment was started (up to 7 months). In the experiments carried out in this study, 363 care was taken to remove or minimize any Fe oxides or sulfates from surfaces prior to 364 dissolution (Paschka and Dzombak, 2004; Liu et al., 2008b); our Fe isotope results suggest that 365 these surface coatings were successfully removed.

366 Iron isotope fractionation in solution and the solid phase during pyrite dissolution provides 367 insights into the dissolution processes involved. Theoretical studies by Polyakov and Mineev 368 (2000) and Schauble et al. (2001) suggest that Fe in pyrite should be isotopically heavier than 369 coexisting aqueous Fe(III) at equilibrium. Butler et al. (2005) found measurable isotope 370 fractionation between aqueous Fe(II) and solid FeS (mackinawite) in precipitation experiments; 371 they calculated a kinetic fractionation factor, $\Delta_{\mathrm{Fe}(\mathrm{II}) \mathrm{FeS}}\left(\delta^{56} \mathrm{Fe}\right.$ of $\mathrm{Fe}(\mathrm{II})[\mathrm{aq}]-\delta^{56} \mathrm{Fe}$ of $\left.\mathrm{FeS}[\mathrm{s}]\right)$, of $3720.85 \pm 0.30 \%$, and an equilibrium fractionation factor of $\sim 0.3 \%$. Thus, in their experiments, the 373 solid FeS was isotopically lighter than the aqueous Fe(II). Equilibrium pyrite precipitation 374 experiments at $300-350^{\circ} \mathrm{C}$ by Syverson et al. (2013) yielded a fractionation factor of $0.99 \%$, in 
good agreement with theoretical calculations. Further work by Guilbaud et al. (2011) demonstrated kinetic isotope fractionations, $\Delta_{\mathrm{Fe}(\mathrm{II})-\mathrm{FeS} 2} \approx \Delta_{\mathrm{FeS}-\mathrm{FeS} 2}$, of +1.7 to $+3.0 \%$ o during pyrite

377 precipitation experiments, which they attribute to a change in coordination from $\mathrm{Fe}(\mathrm{II})_{\mathrm{aq}}$ to

378 Fe(II) $)_{\text {pyrite. }}$ Czaja et al. (2012) argued that these large fractionations resulted from the rapid 379 precipitation of pyrite during laboratory experiments, and that such fractionation would not be 380 present in geologic environments where pyrite forms slowly. While isotope fractionation is expected and experimentally observed between pyrite and $\mathrm{Fe}(\mathrm{II})_{\mathrm{aq}}$, it is not clear to what extent these experiments can be translated to oxidative dissolution of pyrite. The data obtained in our

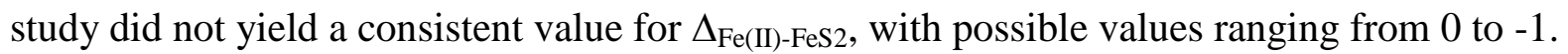
While the direction of fractionation generally agrees with theoretical predictions (Polyakov and Mineev, 2000), there may be other processes controlling the $\delta^{56} \mathrm{Fe}$ of the pyrite leachates. The dissolution of pyrite is an oxidation-reduction reaction and involves the movement of charge across the solid-solution phase boundary (Crundwell, 2013 and references therein). Kavner et al. (2005; 2009) and Black et al. (2010), for example, demonstrated a voltage-dependent Fe fractionation associated with the kinetic effects of electron transfer. The fraction of Fe released 390 from the pyrite in our experiments was $<2 \%$ of the total pyrite placed in the reactors, precluding 391 a total mass balance calculation.

392 As discussed earlier and shown in Figures 3 and 4, the molar S/Fe ratio increased over the 393 course of most dissolution experiments. This increase corresponded with the generally observed 394 but less consistent decrease in $\delta^{56} \mathrm{Fe}$ values during the dissolution experiments. A change in 395 reaction pathway from, for example, the multistep process summarized in Equation (2) to 396 stoichiometric pyrite dissolution (Eq. 1), as discussed in Section 3.2, could affect the Fe isotope 397 composition of the reaction products. However, there is no clear correlation between the S/Fe 398 ratio (cumulative or instantaneous) and shifts in $\delta^{56} \mathrm{Fe}$ over the course of the experiments. While 
399 kinetic isotope fractionation effects could also contribute to changes in the leachate $\delta^{56} \mathrm{Fe}$, 400 modeling by Visual MINTEQ indicates that pyrite is near equilibrium with the fluid during the 401 dissolution reactions reported here.

402 Another possible explanation for the decreasing $\delta^{56} \mathrm{Fe}$ values seen in most of the leachates is 403 that some of the initial excess Fe (relative to $\mathrm{S}$ ) in solution could have been resorbed on the 404 pyrite surface as Fe(III), which would be expected to be enriched in heavy Fe. Thus, by mass 405 balance, the $\delta^{56} \mathrm{Fe}$ of the remaining solution would decrease. This is consistent with the 406 observation that the sample with the greatest surface area (SED-COAL-3; Table 1), therefore 407 possibly with the greatest capacity to resorb Fe, shows the largest decrease in $\delta^{56} \mathrm{Fe}$ at the end of 408 the experimental period (Figs. 5, 6). Both ferrous and traces of ferric iron (hydr)oxides have 409 been detected on the pyrite surface, within the domain of acid $\mathrm{pH}(\mathrm{pH} \leq 4)$, using various 410 analytical techniques (Bonnissel-Gissinger et al., 1998; Rosso and Vaughan, 2006) and 411 speciation modeling (Evangelou, 1995). Fernandez and Borrok (2009) saw evidence of Fe(III) 412 in their $\mathrm{pH}=5$ leaching studies of sulfide-rich rocks, although they did not present $\mathrm{S}$ 413 concentrations from their leaching experiments to allow complete comparison of the 414 experimental data. However, modeling with Visual MINTEQ indicates that hematite $\left(\mathrm{Fe}_{2} \mathrm{O}_{3}\right)$, 415 goethite $(\mathrm{FeO}(\mathrm{OH}))$, and other $\mathrm{Fe}(\mathrm{III})$ species are undersaturated in all of the experiments 416 reported here, arguing against an Fe(III) deposition mechanism.

417 Morimoto (1992) suggested that the molar ratio of $(\mathrm{As}+\mathrm{Sb}) /(\mathrm{Co}+\mathrm{Ni})$ is an indicator of pyrite 418 thermoelectric potential, and Liu et al. (2008b) found that this ratio correlated somewhat with the 419 calculated dissolution rate, with much higher dissolution rates for samples in which the ratio was $420>1$. They suggested that this could be due to differences in corrosion by electron holes and 421 conductivity (see Lehner et al., 2007). However, we did not find any significant correlations of 
422 Fe isotope ratios or shifts in the ratio over time with $(\mathrm{As}+\mathrm{Sb}) /(\mathrm{Co}+\mathrm{Ni})$, or with any other trace 423 element reported from the dissolution experiments by Liu (2007) and Liu et al. (2008b).

424 Some of the shifts in $\delta^{56} \mathrm{Fe}$ of the leachates could also conceivably be caused by isotopic 425 heterogeneity of the pyrite itself. Pyrite in the natural environment is likely to form over long 426 time periods from fluids that could contain multiple sources and generations of Fe. This is likely 427 to be especially true in sedimentary pyrite, which forms diagenetically in subsiding basins in 428 which the Fe might be expected to evolve continuously over time (e.g., Severmann et al., 2006).

429 While the leachates from both the hydrothermal and the sedimentary pyrite examined in this 430 study exhibited significant variations in $\delta^{56} \mathrm{Fe}$, the largest variations were observed in 431 sedimentary coal sample SED-COAL-3 and fossil replacement SED-2. In particular, SED-2 had 432 a change in $\delta^{56} \mathrm{Fe}$ of almost $1 \%$ from 480 to 1440 minutes, and in the opposite direction of most 433 other samples (Figs. 5, 6). This shift could represent a change in dissolution from low- to high$434 \delta^{56} \mathrm{Fe}$ pyrite within the sample, with possible isotopic shifts correlating with morphological 435 changes that affect the ease of dissolution. In situ Fe isotope analyses of sedimentary pyrite by 436 laser ablation (Nishizawa et al., 2010) and SIMS (Whitehouse and Fedo, 2007; Virtasalo et al., 437 2013; Marin-Carbonne et al., 2014) indicates significant shifts in $\delta^{56} \mathrm{Fe}$ even within individual 438 grains or nodules. Similar variations were seen in pyrite from massive sulfide deposits (Graham 439 et al., 2004). Nonetheless, the observation that nearly all leachates in the experiments reported 440 here shifted to lower $\delta^{56} \mathrm{Fe}$ values over the course of the experiment (Fig. 7) argues that pyrite 441 heterogeneity is a secondary effect in most cases. Resolution of this issue will require 442 experiments on demonstrably isotopically uniform pyrite, perhaps prepared synthetically under 443 carefully controlled conditions. 


\section{Conclusions}

446 Oxidative dissolution experiments were carried out on pyrite from multiple petrogenetic 447 environments to investigate possible variations in the Fe isotopic composition of pyrite and 448 pyrite leachates. The experimental materials were separated into aliquots of uniform grain size 449 (after Wolfe et al., 2007), and were dissolved under carefully controlled conditions (Liu et al., 450 2008b). A subset of samples from these experiments was analyzed for ${ }^{56} \mathrm{Fe} /{ }^{54} \mathrm{Fe}$ by 451 multicollector ICP-MS.

452 Bulk pyrite $\delta^{56} \mathrm{Fe}$ values ranged from -0.1 to +1.3 , with hydrothermal bulk pyrite $\delta^{56} \mathrm{Fe}<0.5$ 453 and coal and sedimentary pyrite nodule $\delta^{56} \mathrm{Fe} \geq 0.5$. The hydrothermal bulk pyrite $\delta^{56} \mathrm{Fe}$ value is 454 within the range of previously analyzed hydrothermal pyrite, but the coal/sedimentary values are 455 higher than those of previously analyzed pre-Holocene Phanerozoic sedimentary pyrite. We 456 suggest that this reflects precipitation of pyrite from a high- $\delta^{56} \mathrm{Fe}$ continental source, such as $\mathrm{Fe}$ 457 derived from dissolution of Fe(III) oxides.

458 Leachates from oxidative dissolution of pyrite at $\mathrm{pH}=3$ generally yielded $\delta^{56} \mathrm{Fe}$ values equal 459 to or below those of the coexisting bulk pyrite, by up to $\sim 1 \%$, and in most cases, the $\delta^{56} \mathrm{Fe}$ values 460 of the pyrite leachates decreased with time of reaction. Although the observed shifts were not 461 consistent in magnitude, the direction of fractionation was consistent with theoretical predictions 462 (Polyakov and Mineev, 2000). Release of Fe from different portions of isotopically 463 heterogeneous pyrite grains may be a secondary effect in some cases.

464 Results of this study demonstrate that Fe isotopes can yield important information about 465 surface processes during oxidative dissolution of pyrite. $\delta^{56} \mathrm{Fe}$ values can also be used to 466 distinguish between waters that interacted with continentally-derived pyrite (e.g., from coal) and 467 pyrite formed under marine or hydrothermal conditions. This suggests that Fe isotopes could be 
468 a useful tool for tracking Fe sources and biogeochemical processes that operate in coal mine 469 drainage systems.

470

\section{Acknowledgments}

472 This work was supported by the National Science Foundation under Grants EAR-0229019

473 (R.C.C./B.W.S.) and EAR-0228903 (D.A.D.). We thank two anonymous reviewers for

474 comments that greatly improved the manuscript, and C. M. Koretsky for editorial handling. 475 
476

477

478

479

480

481

482

483

484

485

486

487

488

489

490

491

492

493

494

495

496

497

498

499

\section{References}

Anbar, A.D., Roe, J.E., Barling, J., Nealson, K.H., 2000. Non-biological fractionation of iron isotopes. Science 288, 126-128.

Anders, E., Grevasse, N., 1989. Abundances of the elements: Meteoritic and solar. Geochim. Cosmochim. Acta 53, 197-214.

Archer, C., Vance, D., 2006. Coupled Fe and S isotope evidence for Archean microbial Fe(III) and sulfate reduction. Geology 34, 153-156.

Arnold, G.L., Weyer, S., Anbar, A.D., 2004. Fe isotope variations in natural materials measured using high mass resolution multiple collector ICPMS. Anal. Chem. 76, 322-327.

Beard, B.L., Johnson, C.M., 1999. High precision iron isotope measurements of terrestrial and lunar materials. Geochim. Cosmochim. Acta 63, 1653-1660.

Bergquist, B.A., Boyle, E.A., 2006. Iron isotopes in the Amazon River system: Weathering and transport signatures. Earth Planet. Sci. Lett. 248, 54-68.

Berner, R.A., 1984. Sedimentary pyrite formation: an update. Geochim. Cosmochim. Acta 48, 605-615.

Black, J.R., Young, E.D., Kavner, A., 2010. Electrochemically controlled iron isotope fractionation. Geochim. Cosmochim. Acta 74, 809-817.

Bonnissel-Gissinger, P., Alnot, M., Ehrhardt, J.-J., Behra, P., 1998. Surface oxidation of pyrite as a function of pH. Environ. Sci. Technol. 32, 2839-2845.

Borrok, D.M., Wanty, R.B., Ridley, W.I., Lamothe, P.J., Kimball, B.A., Verplanck, P.L., Runkel, R.L., 2009. Application of iron and zinc isotopes to track the sources and mechanisms of metal loading in a mountain watershed. Appl. Geochem. 24, 1270-1277.

Bullen, T.D., White, A.F., Childs, C.W., Vivit, D.V., Schulz, M.S., 2001a. Demonstration of significant abiotic iron isotope fractionation in nature. Geology 29, 699-702. 
Bullen, T.D., White, A.F., Childs, C.W., Vivit, D.V., Schulz, M.S., 2001b. Field, experimental, and mass spectrometry techniques and data (Supplement to Geology article "Demonstration of significant abiotic iron isotope fractionation in nature"). GSA Data Repository item 2001083.

Busigny, V., Planavsky, N.J., Jézéquel, D., Crowe, S., Louvat, P., Moureau, J., Viollier, E., Lyons, T.W., 2014. Iron isotopes in an Archean ocean analogue. Geochim. Cosmochim. Acta $133,443-462$.

Butler, I.B., Archer, C., Vance, D., Oldroyd, A., Rickard, D., 2005. Fe isotope fractionation on FeS formation in ambient aqueous solution. Earth Planet. Sci. Lett. 236, 430-442.

Canfield, D.E., 1989. Reactive iron in marine sediments. Geochim. Cosmochim. Acta 53, 619632.

Canfield, D.E., Raiswell, R., Bottrell, S., 1992. The reactivity of sedimentary iron minerals toward sulfide. Am. J. Sci. 292, 659-683.

Chen, D., Chen, G., Pan, J., Ma, S., Dong, W., Gao, J., Chen, X., 1998. Hydrothermal sedimentation characteristics of the Dajiangping superlarge pyrite deposit, Yunfu, Guangdong. Chin. J. Geochem. 17, 331-337.

Colt, J., 2012. Dissolved Gas Concentration in Water: Computation as Functions of Temperature, Salinity, and Pressure. Elsevier, London, 306 p.

Crundwell, F.K., 2013. The dissolution and leaching of minerals: Mechanisms, myths and misunderstandings. Hydrometallurgy 139, 132-148.

Czaja, A.D., Johnson, C.M., Beard, B.L., Eigenbrode, J.L., Freeman, K.H., Yamaguchi, K.E., 2010. Iron and carbon isotope evidence for ecosystem and environmental diversity in the $\sim 2.7$ to 2.5 Ga Hamersley Province, Western Australia. Earth Planet. Sci. Lett. 292, 170-180.

Czaja, A.D., Johnson, C.M., Yamaguchi, K.E., Beard, B.L., 2012. Comment on "Abiotic pyrite formation produces a large Fe isotope fractionation". Science 335, 538. 
525 Descostes, M., Vitorge, P., Beaucaire, C., 2004. Pyrite dissolution in acidic media. Geochim. 526 Cosmochim. Acta 68, 4559-4569.

527 Druschel, G., Borda, M.J., 2006. Comment on "Pyrite dissolution in acidic media" by M. 528 Descostes, P. Vitorge, and C. Beaucaire. Geochim. Cosmochim. Acta 70, 5246-5250.

529 Duan, Y., Severmann, S., Anbar, A.D., Lyons, T.W., Gordon, G.W., Sageman, B.B., 2010.

530 Isotopic evidence for $\mathrm{Fe}$ cycling and repartitioning in ancient oxygen-deficient settings:

531 Examples from black shales of the mid-to-late Devonian Appalachian basin. Earth Planet.

532 Sci. Lett. 290, 244-253.

533 Emmanuel, S., Erel, Y., Matthews, A., Teutsch, N., 2005. A preliminary mixing model for Fe 534 isotopes in soils. Chem. Geol. 222, 23-34.

535 Evangelou, V.P., 1995. Pyrite Oxidation and its Control. CRC Press, Boca Raton, FL, 293 p.

536 Fabre, S., Nédélec, A., Poitrasson, F., Strauss, H., Thomazo, C., Nogueira, A., 2011. Iron and 537 sulphur isotopes from the Carajás mining province (Pará, Brazil): Implications for the 538 oxidation of the ocean and the atmosphere across the Archaean-Proterozoic transition. 539 Chem. Geol. 289, 124-139.

540 Fantle, M.S., DePaolo, D.J., 2004. Iron isotope fractionation during continental weathering. 541 Earth Planet. Sci. Lett. 228, 547-562.

542 Fehr, M.A., Andersson, P.S., Hålenius, U., Carl-Magnus, M., 2008. Iron isotope variations in 543 Holocene sediments of the Gotland Deep, Baltic Sea. Geochim. Cosmochim. Acta 72, 807544826.

545 Fehr, M.A., Andersson, P.S., Hålenius, U., Gustafsson, Ö., Mörth, C.-M., 2010. Iron enrichments 546 and Fe isotopic compositions of surface sediments from the Gotland Deep, Baltic Sea. Chem. 547 Geol. 277, 310-322.

548 Fernandez, A., Borrok, D.M., 2009. Fractionation of $\mathrm{Cu}, \mathrm{Fe}$, and $\mathrm{Zn}$ isotopes during the 549 oxidative weathering of sulfide-rich rocks. Chem. Geol. 264, 1-12. 
Fralick, P.W., Barrett, T.J., Jarvis, K.E., Jarvis, I., Schneiders, B.R., Vande Kemp, R., 1989. Sulfide-facies iron formation a the Archean Morley occurrence, northwestern Ontario: Contrasts with oceanic hydrothermal deposits. Canadian Mineralogist 27, 601-616.

553 Graham, S., Pearson, N., Jackson, S., Griffin, W., O'Reilly, S.Y., 2004. Tracing Cu and Fe from 554 source to porphyry: in situ determination of $\mathrm{Cu}$ and $\mathrm{Fe}$ isotope ratios in sulfides from the 555 Grasberg $\mathrm{Cu}-\mathrm{Au}$ deposit. Chem. Geol. 207, 147-169.

556 Gromet, L.P., Dymek, R.F., Haskin, L.A., Korotev, R.L., 1984. The "North American shale composite": Its compilation, major and trace element characteristics. Geochim. Cosmochim.

559 Guilbaud, R., Butler, I.B., Ellam, R.M., 2011. Abiotic pyrite formation produces a large Fe 560 Acta 48, 2469-2482.

Gustafsson, J.P., 2012. Visual MINTEQ, v. 3.0. Available at: http://vminteq.lwr.kth.se/.

Herbert, R.B., Jr., Schippers, A., 2008. Iron isotope fractionation by biogeochemical processes in mine tailings. Environ. Sci. Technol. 42, 1117-1122.

Hofmann, A., Bekker, A., Rouxel, O.J., Rumble, D., III, Master, S., 2009. Multiple sulphur and iron isotope composition of detrital pyrite in Archaean sedimentary rocks: A new tool for provenance analysis. Earth Planet. Sci. Lett. 286, 436-445.

Holmes, P.R., Crundwell, F.K., 2000. The kinetics of the oxidation of pyrite by ferric ions and dissolved oxygen: An electrochemical study. Geochim. Cosmochim. Acta 64, 263-274.

Icopini, G.A., Anbar, A.D., Ruebush, S.S., Tien, M., Brantley, S.L., 2004. Iron isotope fractionation during microbial reduction of iron: The importance of adsorption. Geology 32 , 205-208.

573 Ö., Forsling, W., Öhlander, B., 2006. Iron isotope fractionation in river colloidal matter.

$574 \quad$ Earth Planet. Sci. Lett. 245, 792-798. 
575

ISO (International Organization for Standardization), 2010. Determination of the specific surface area of solids by gas adsorption - BET method (ISO 9277:2010(E)). International Organization for Standardization: Geneva, 30 pp. (Preceded by ISO 9277:1995).

Johnson, C.M., Beard, B.L., 1999. Correction of instrumentally produced mass fractionation during isotopic analysis of Fe by thermal ionization mass spectrometry. Int. J. Mass Spectrom. 193, 87-99.

Johnson, C.M., Beard, B.L., Beukes, N.J., Klein, C., O'Leary, J.M., 2003. Ancient geochemical cycling in the Earth as inferred from Fe isotope studies of banded iron formations from the Transvaal Craton. Contrib. Mineral. Petrol. 144, 523-547.

Johnson, C.M., Beard, B.L., Roden, E.E., 2008. The iron isotope fingerprints of redox and biogeochemical cycling in modern and ancient Earth. Ann. Rev. Earth Planet. Sci. 36, 457493.

Kavner, A., Bonet, F., Shahar, A., Simon, J., Young, E., 2005. The isotopic effects of electron transfer: An explanation for Fe isotope fractionation in nature. Geochim. Cosmochim. Acta 69, 2971-2979.

Kavner, A., Shahar, A., Black, J.R., Young, E.D., 2009. Iron isotope electroplating: Diffusionlimited fractionation. Chem. Geol. 267, 131-138.

Lehner, S., Savage, K., Ciobanu, M., Cliffel, D.E., 2007. The effect of As, Co, and Ni impurities on pyrite oxidation kinetics: An electrochemical study of synthetic pyrite. Geochim. Cosmochim. Acta 71, 2491-2509.

Liu, R., 2007. Electrochemical Study of Pyrite Dissolution. Ph.D. Thesis, Carnegie Mellon University.

Liu, R., Wolfe, A.L., Dzombak, D.A., Horwitz, C.P., Stewart, B.W., Capo, R.C., 2008a. Electrochemical study of hydrothermal and sedimentary pyrite dissolution. Appl. Geochem. 23, 2724-2734. 
Liu, R., Wolfe, A.L., Dzombak, D.A., Stewart, B.W., Capo, R.C., 2008b. Comparison of dissolution under oxic acid drainage conditions for eight sedimentary and hydrothermal pyrite samples. Environ. Geol. 56, 171-182.

Liu, R., Wolfe, A.L., Dzombak, D.A., Horwitz, C.P., Stewart, B.W., Capo, R.C., 2009. Controlled electrochemical dissolution of hydrothermal and sedimentary pyrite. Appl. Geochem. 24, 836-842.

Maréchal, C., Télouk, P., Albarède, F., 1999. Precise analysis of copper and zinc isotopic compositions by plasma-source mass spectrometry. Chem. Geol. 156, 251-273.

Marin-Carbonne, J., Rollion-Bard, C., Bekker, A., Rouxel, O., Agangi, A., Cavalazzi, B., Wohlgemuth-Ueberwasser, C.C., Hofmann, A., McKeegan, K.D., 2014. Coupled Fe and S isotope variations in pyrite nodules from Archean shale. Earth Planet. Sci. Lett. 392, 67-79.

Matthews, A., Morgans-Bell, H.S., Emmanuel, S., Jenkyns, H.C., Erel, Y., Halicz, L., 2004. Controls on iron-isotope fractionation in organic-rich sediments (Kimmeridge Clay, Upper Jurassic, southern England). Geochim. Cosmochim. Acta 68, 3107-3123.

McKibben, M.A., Barnes, H.L., 1986. Oxidation of pyrite in low temperature acidic solutions: rate laws and surface textures. Geochim. Cosmochim. Acta 50, 1509-1520.

McLennan, S.M., 1989. Rare earth elements in sedimentary rocks: Influence of provenance and sedimentary processes. In: B.R. Lipin and G.A. McKay (Eds.), Geochemistry and Mineralogy of Rare Earth Elements. Reviews in Mineralogy 21, Mineralogical Society of America, Chelsea, Michigan, pp. 169-200.

Mills, R.A., Elderfield, H., 1995. Rare earth element geochemistry of hydrothermal deposits from the active TAG Mound, $26^{\circ} \mathrm{N}$ Mid-Atlantic Ridge. Geochim. Cosmochim. Acta 59, 3511-3524.

Morgan, J.L.L., Wasylenki, L.E., Nuester, J., Anbar, A.D., 2010. Fe isotope fractionation during equilibration of Fe-organic complexes. Environ. Sci. Technol. 44, 6095-6101.

Morimoto, K., 1992. Roles of Trace Elements in the Variation of Physical and Mineralogical Properties of Natural Pyrite Crystals. M.S. Thesis, Tohoku University. 
Moses, C.O., Herman, J.S., 1991. Pyrite oxidation at circumneutral pH. Geochim. Cosmochim. Acta 55, 471-482.

Moses, C.O., Nordstrom, D.K., Herman, J.S., Mills, A.L., 1987. Aqueous pyrite oxidation by dissolved oxygen and by ferric iron. Geochim. Cosmochim. Acta 51, 1561-1571.

Nishizawa, M., Yamamoto, H., Ueno, Y., Tsuruoka, S., Shibuya, T., Sawaki, Y., Yamamoto, S., Kon, Y., Kitajima, K., Komiya, T., Maruyama, S., Hirata, T,, 2010. Grain-scale iron isotopic distribution of pyrite from Precambrian shallow marine carbonate revealed by a femtosecond laser ablation multicollector ICP-MS technique: Possible proxy for the redox state of ancient seawater. Geochim. Cosmochim. Acta 74, 2760-2778.

Paschka, M.G., Dzombak, D.A., 2004. Use of dissolved sulfur species to measure pyrite dissolution in water at pH 3 and 6. Environ. Engin. Sci. 21, 411-420.

Polyakov, V.B., Mineev, S.D., 2000. The use of Mössbauer spectroscopy in stable isotope geochemistry. Geochim. Cosmochim. Acta 64, 849-865.

Rickard, D., Luther, G.W., III, 2007. Chemistry of iron sulfides. Chem. Rev. 107, 514-562.

Rosso, K.M., Vaughan, D.J., 2006. Reactivity of sulfide mineral surfaces. In: D.J. Vaughan (Ed.), Sulfide Mineralogy and Geochemistry. Reviews in Mineralogy and Geochemistry 61, The Mineralogical Society of America, Chantilly, Virginia, pp. 557-607.

Rouxel, O., Bekker, A., Edwards, K.J., 2005. Iron isotope constraints on the Archean and Paleoproterozoic ocean redox state. Science 307, 1088-1091.

Rouxel, O., Dobbek, N., Ludden, J., Fouquet, Y., 2003. Iron isotope fractionation during oceanic crust alteration. Chem. Geol. 202, 155-182.

Rouxel, O., Fouquet, Y., Ludden, J.N., 2004. Subsurface processes at the Lucky Strike hydrothermal field, Mid-Atlantic Ridge: Evidence from sulfur, selenium, and iron isotopes. Geochim. Cosmochim. Acta 68, 2295-2311.

Rouxel, O., Shanks, W.C., III, Bach, W., Edwards, K.J., 2008. Integrated Fe- and S-isotope study of seafloor hydrothermal vents at East Pacific Rise 9-10N. Chem. Geol. 252, 214-227. 
Schatzel, S.J., Stewart, B.W., 2003. Rare earth element sources and modification in the Lower

654 Kittanning coal bed, Pennsylvania: implications for the origin of coal mineral matter and rare earth element exposure in underground mines. Int. J. Coal Geol. 54, 223-251.

656 Schauble, E.A., Rossman, G.R., Taylor, H.P., Jr., 2001. Theoretical estimates of equilibrium Feisotope fractionations from vibrational spectroscopy. Geochim. Cosmochim. Acta 65, 2487-

Scholz, F., Severmann, S., McManus, J., Noffke, A., Lomnitz, U., Hensen, C., 2014. On the isotope composition of reactive iron in marine sediments: Redox shuttle versus early diagenesis. Chem. Geol. 389, 48-59.

Severmann, S., Johnson, C.M., Beard, B.L., McManus, J., 2006. The effect of early diagenesis on the Fe isotope compositions of porewaters and authigenic minerals in continental margin sediments. Geochim. Cosmochim. Acta 70, 2006-2022.

Severmann, S., Lyons, T.W., Anbar, A.D., McManus, J., Gordon, G.W., 2008. Modern iron isotope perspective on the benthic iron shuttle and the redox evolution of ancient oceans. Geology 36, 487-490.

Sharma, M., Polizzotto, M., Anbar, A.D., 2001. Iron isotopes in hot springs along the Juan de Fuca Ridge. Earth Planet. Sci. Lett. 194, 39-51.

Singer, P.C., Stumm, W., 1970. Acid mine drainage: the rate-determining step. Science 167, 1121-1123.

Song, X., Xu, Q., Guo, Y., Mao, X., Ouyang, H., 1997. REE geochemistry of VMS and SEDEX ores in China. Acta Geol. Sin. 71, 263-272.

Syverson, D.D., Borrok, D.M., Seyfried, W.E., Jr., 2013. Experimental determination of equilibrium $\mathrm{Fe}$ isotopic fractionation between pyrite and dissolved $\mathrm{Fe}$ under hydrothermal conditions. Geochim. Cosmochim. Acta 122, 170-183.

Toner, B.M., Fakra, S.C., Manganini, S.J., Santelli, C.M., Marcus, M.A., Moffett, J.W., Rouxel, O., German, C.R., Edwards, K.J., 2009. Preservation of iron(II) by carbon-rich matrices in a hydrothermal plume. Nature Geosci. 2, 197-201. 
US EPA, 2007. Method 6010C: Inorganics by ICP-AES, Revision 3, Test Methods for Evaluating Solid Waste: EPA Publication SW-846, Office of Solid Waste, Washington DC.

Vaughan, D.J., 2006. Sulfide mineralogy and geochemistry: Introduction and overview. In: D.J. Vaughan (Ed.), Sulfide Mineralogy and Geochemistry. Reviews in Mineralogy and Geochemistry 61, The Mineralogical Society of America, Chantilly, Virginia, pp. 1-5.

Virtasalo, J.J., Whitehouse, M.J., Kotilainen, A.T., 2013. Iron isotope heterogeneity in pyrite fillings of Holocene worm burrows. Geology 41, 39-42.

Wawryk, C.M., Foden, J.D., 2015. Fe-isotope fractionation in magmatic-hydrothermal mineral deposits: A case study from the Renison Sn-W deposit, Tasmania. Geochim. Cosmochim. Acta 150, 285-298.

Weber, P.A., Stewart, W.A., Skinner, W.M., Weisener, C.G., Thomas, J.E., Smart, R.S.C., 2004.

Wiese, R.G., Jr., Fyfe, W.S., 1986. Occurrences of iron sulfides in Ohio coals. Int. J. Coal Geol.

Williamson, M.A., Rimstidt, J.D., 1994. The kinetics and electrochemical rate-determining step of aqueous pyrite oxidation. Geochim. Cosmochim. Acta 58, 5443-5454.

Wolfe, A.L., Liu, R., Stewart, B.W., Capo, R.C., Dzombak, D.A., 2007. A method for generating uniform size-segregated pyrite particle fractions. Geochem. Trans. 8, doi: 10.1186/14674866-8-9.

Hirata, T., Wada, H., Maruyama, S., 2012. In situ iron isotope analyses of pyrite and organic carbon isotope ratios in the Fortescue Group: Metabolic variations of a Late Archean ecosystem. Precamb. Res. 212-213, 169-193. 
707 Yoshiya, K., Sawaki, Y., Hirata, T., Maruyama, S., Komiya, T., 2015. In-situ iron isotope

708 analysis of pyrites in $\sim 3.7 \mathrm{Ga}$ sedimentary protoliths from the Isua supracrustal belt, southern

709 West Greenland. Chem. Geol. 401, 126-139.

710 Zhao, K.-D., Jiang, S.-Y., 2007. Rare earth element and yttrium analyses of sulfides from the

711 Dachang Sn-polymetallic ore field, Guangxi Province, China: Implication for ore genesis.

712 Geochem. J. 41, 121-134. 
715 Fig. 1. Rare earth element (REE) patterns for sedimentary and hydrothermal bulk pyrite samples

716 from this study. Also shown for comparison: the North American Shale Composite (NASC;

717 Gromet et al., 1984), and the range of values for Pennsylvanian coal (shaded area) from Schatzel 718 and Stewart (2003).

Fig. 2. Equilibrium speciation of dissolved iron in pyrite dissolution leachates, as a function of

721 pe at $\mathrm{pH}=3$ and $25^{\circ} \mathrm{C}$. Dissolved sulfate $\left(a\left[\mathrm{SO}_{4}{ }^{2-}\right]\right)=10^{-3.3} \mathrm{M}$ and chloride $\left(a\left[\mathrm{Cl}^{-}\right]\right)=10^{-2} \mathrm{M}$.

722 Activity calculations were conducted using Visual MINTEQ (Gustafsson, 2012).

723

724 Fig. 3. Leachate solution molar $\mathrm{S} / \mathrm{Fe}$ ratios for each sampling point during the eight pyrite 725 dissolution experiments at $\mathrm{pH}=3$. Note that the bulk solution composition does not reach the 726 stoichiometric pyrite S:Fe ratio (2:1) after 24 hours.

728 Fig. 4. Calculated $\mathrm{S} / \mathrm{Fe}$ ratio released at each leaching time interval for the $\mathrm{pH}=3$ leaching 729 experiments is plotted against the total amount of pyrite dissolved at the end of that interval.

730 When calculated this way, it can be seen that the Fe and $\mathrm{S}$ being released approaches a ratio 731 close to that of stoichiometric pyrite after $\sim 0.5 \%$ dissolution (contrast with Fig. 3). The dashed 732 exponential curve is shown for comparison only.

734 Fig. 5. Variation in bulk pyrite (closed square) and pyrite leachate (open symbol) $\delta^{56} \mathrm{Fe}$ values. 735 Bulk pyrite values are not available for HY-3, SED-2 and SED-COAL-2. Error bars represent 736 external $2 \sigma$ uncertainty. 
738 Fig. 6. $\delta^{56} \mathrm{Fe}$ of leachate solution sampled at different time intervals during pyrite oxidative 739 dissolution experiments at $\mathrm{pH}=3$. Where available, bulk pyrite values are plotted on the right.

740 Complete dissolution of the samples would bring the solution to the bulk pyrite $\delta^{56} \mathrm{Fe}$ value.

741 Error bars represent external $2 \sigma$ uncertainty.

743 Fig. 7. Leachate $\mathrm{Fe}$ isotopic evolution for $\mathrm{pH}=3$ experiments is shown as the difference between

744 a given leachate $\delta^{56} \mathrm{Fe}$ and that of the first leachate (usually at $60 \mathrm{~min}$ ) for that sample. For

745 sample HY-3, the first leachate analyzed was at 6 hours, and for SED-2, the first analysis was at

7468 hours. In most cases, the leachate $\delta^{56} \mathrm{Fe}$ remained the same or decreased over time; SED-2 is

747 the major exception.

749 Fig. 8. Summary of published Fe isotope data from pyrite of sedimentary and hydrothermal

750 origin (open symbols), with a comparison to values from this study (closed symbols). Note that

751 we report Phanerozoic sedimentary pyrite with significantly positive $\delta^{56}$ Fe values. Published

752 data are from Sharma et al. (2001); Rouxel et al. (2003; 2004; 2005; 2008); Johnson et al.

753 (2003); Graham et al. (2004); Matthews et al. (2004); Archer and Vance (2006); Severmann et

754 al. (2006; 2008); Fehr et al.; (2008; 2010); Hofmann et al. (2009); Duan et al. (2010); Nishizawa

755 et al. (2010); Fabre et al. (2011); Yoshiya et al. (2012; 2015); Marin-Carbonne et al. (2014);

756 Scholz et al. (2014); and Wawryk and Foden (2015). Individual SIMS spot analyses of

757 Holocene diagenetic pyrite from the Baltic Sea (not shown) range from -3.1 to +4.1 (Virtasalo et

758 al., 2013). 


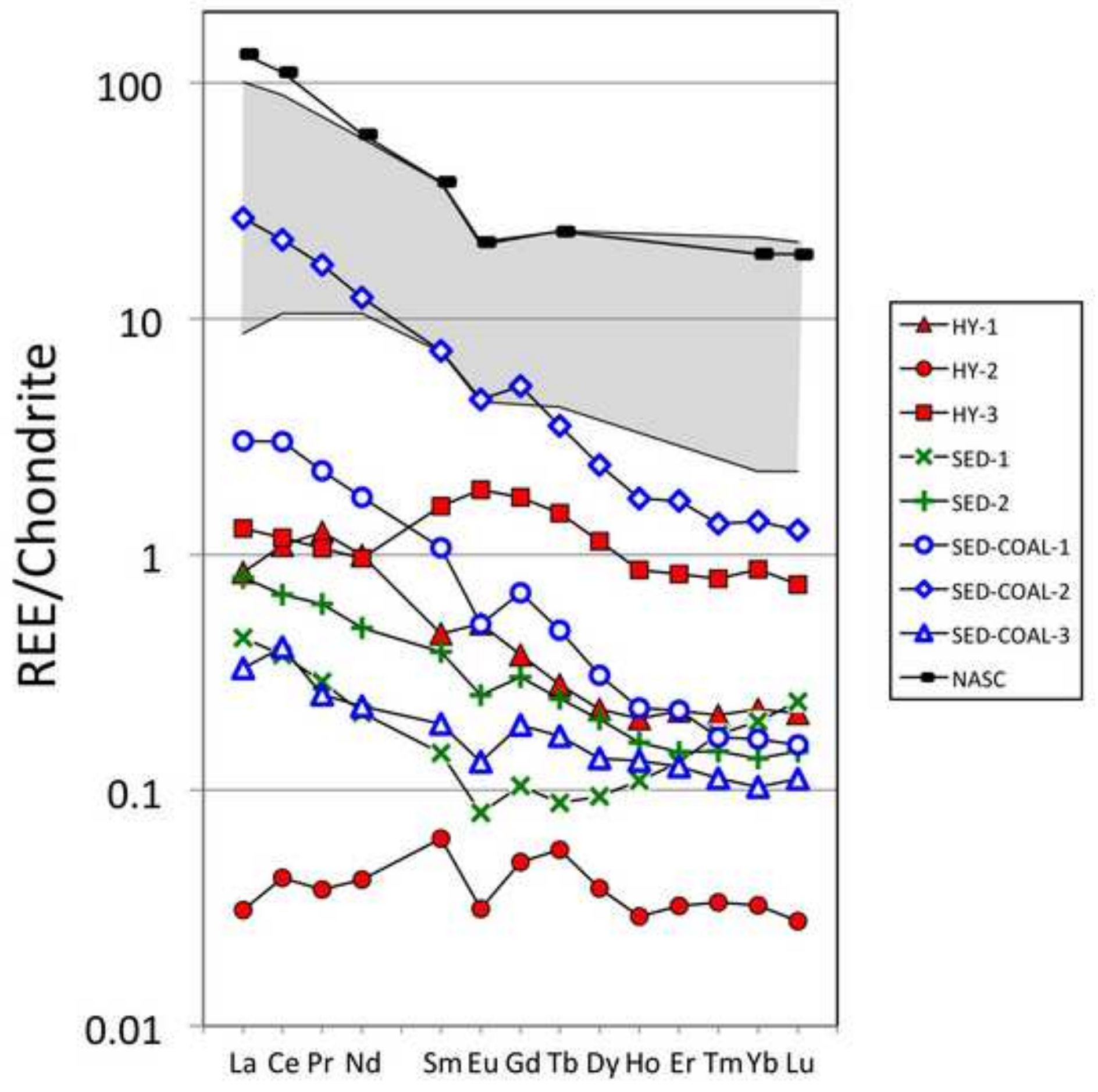




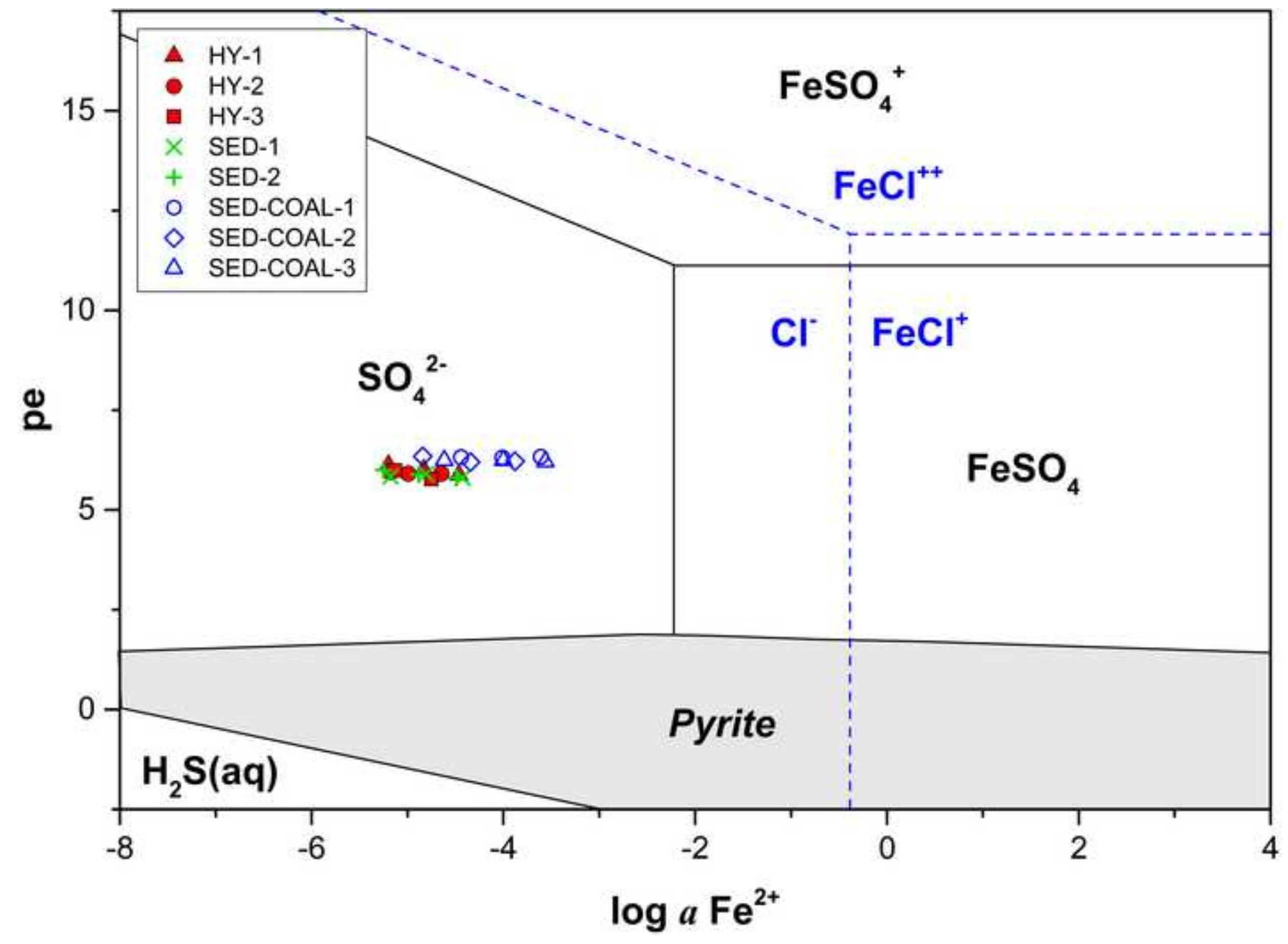




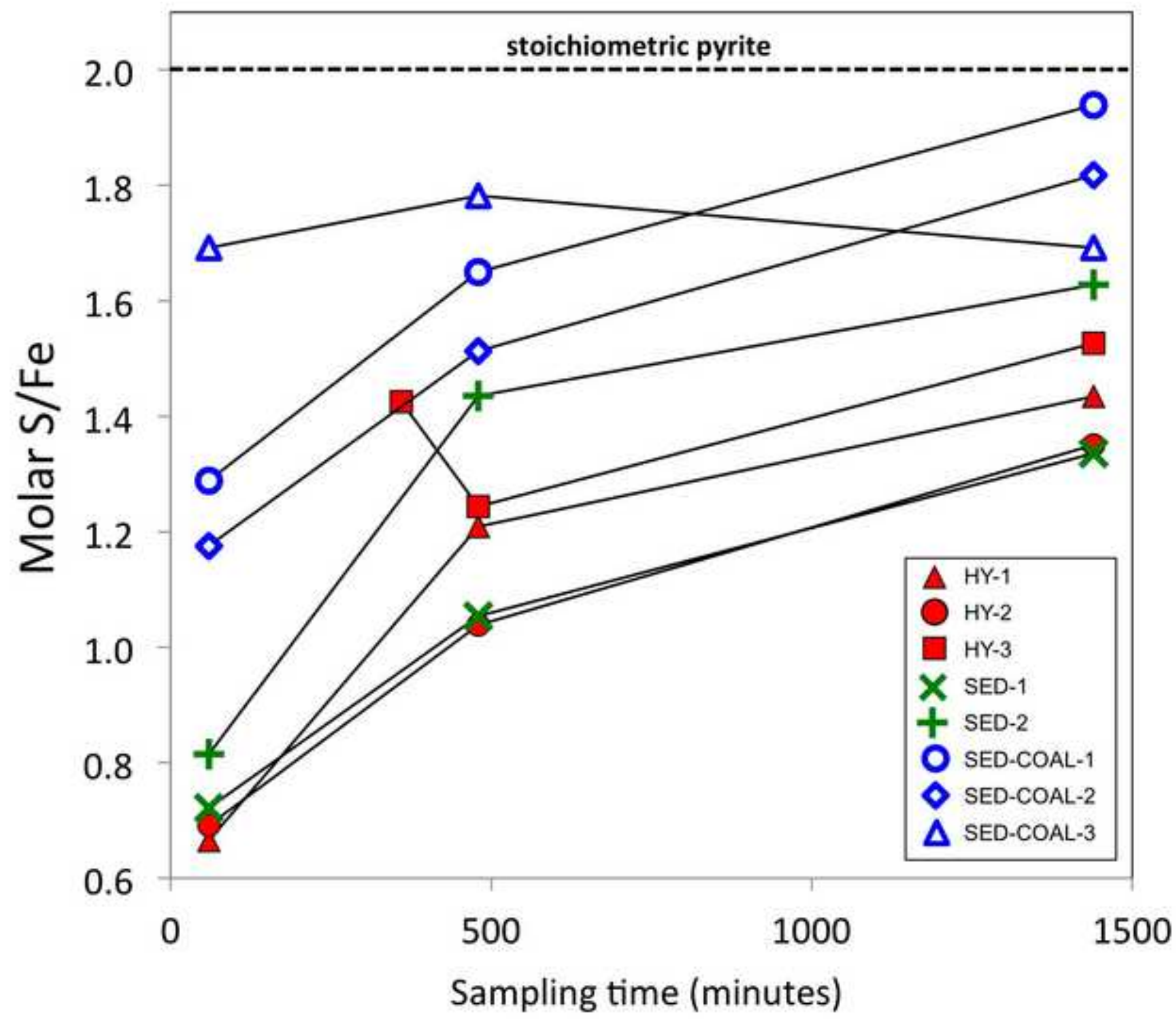




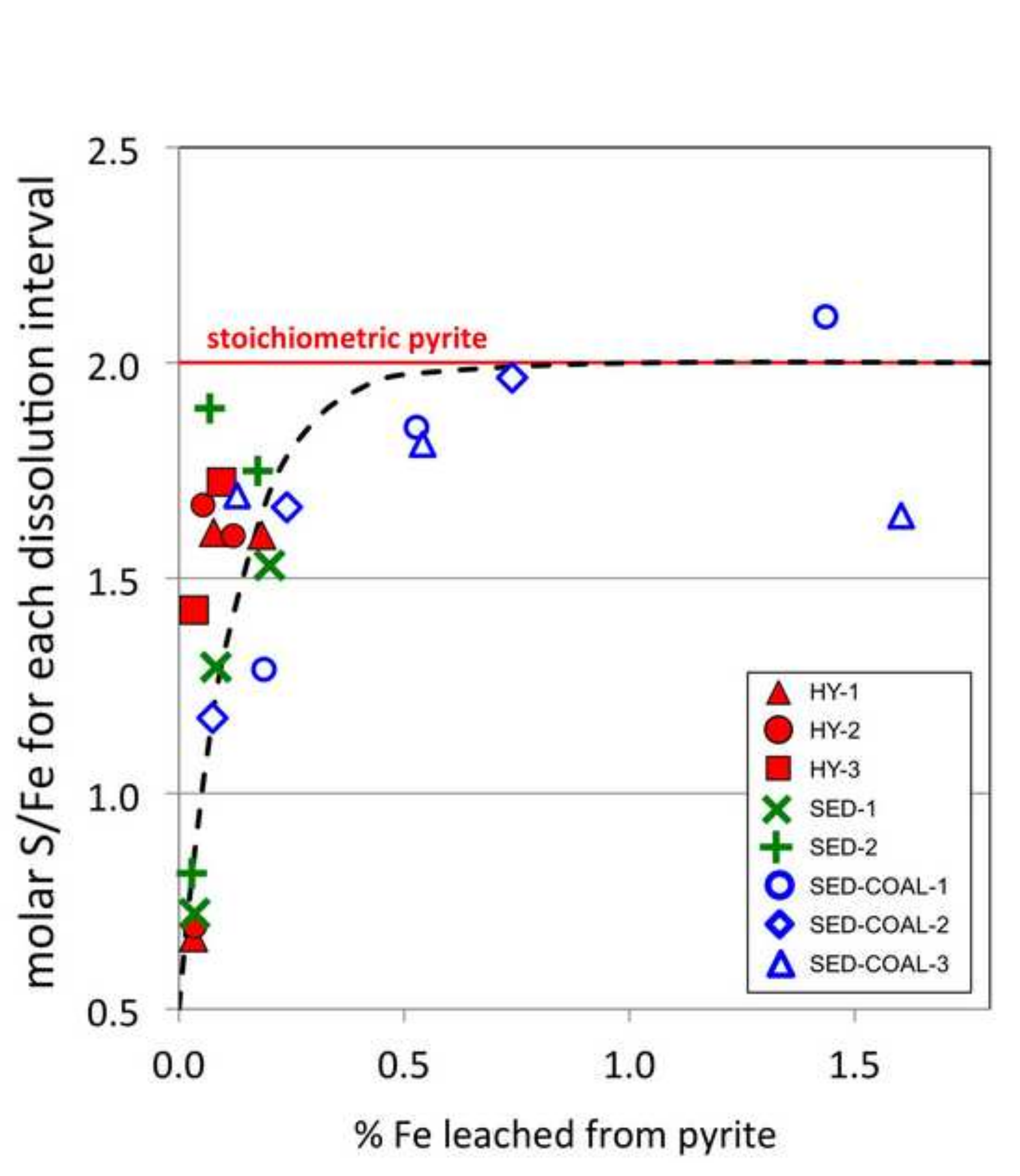

Figure 4

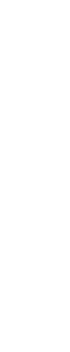

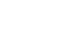

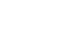

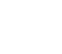

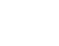
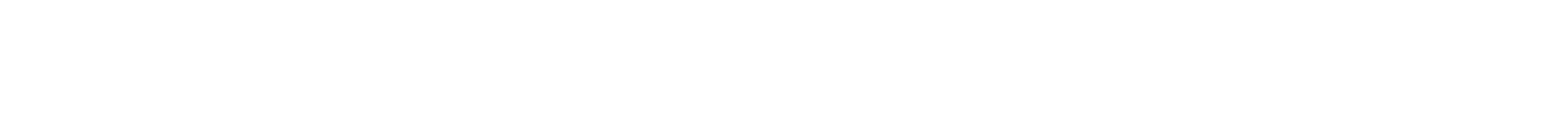


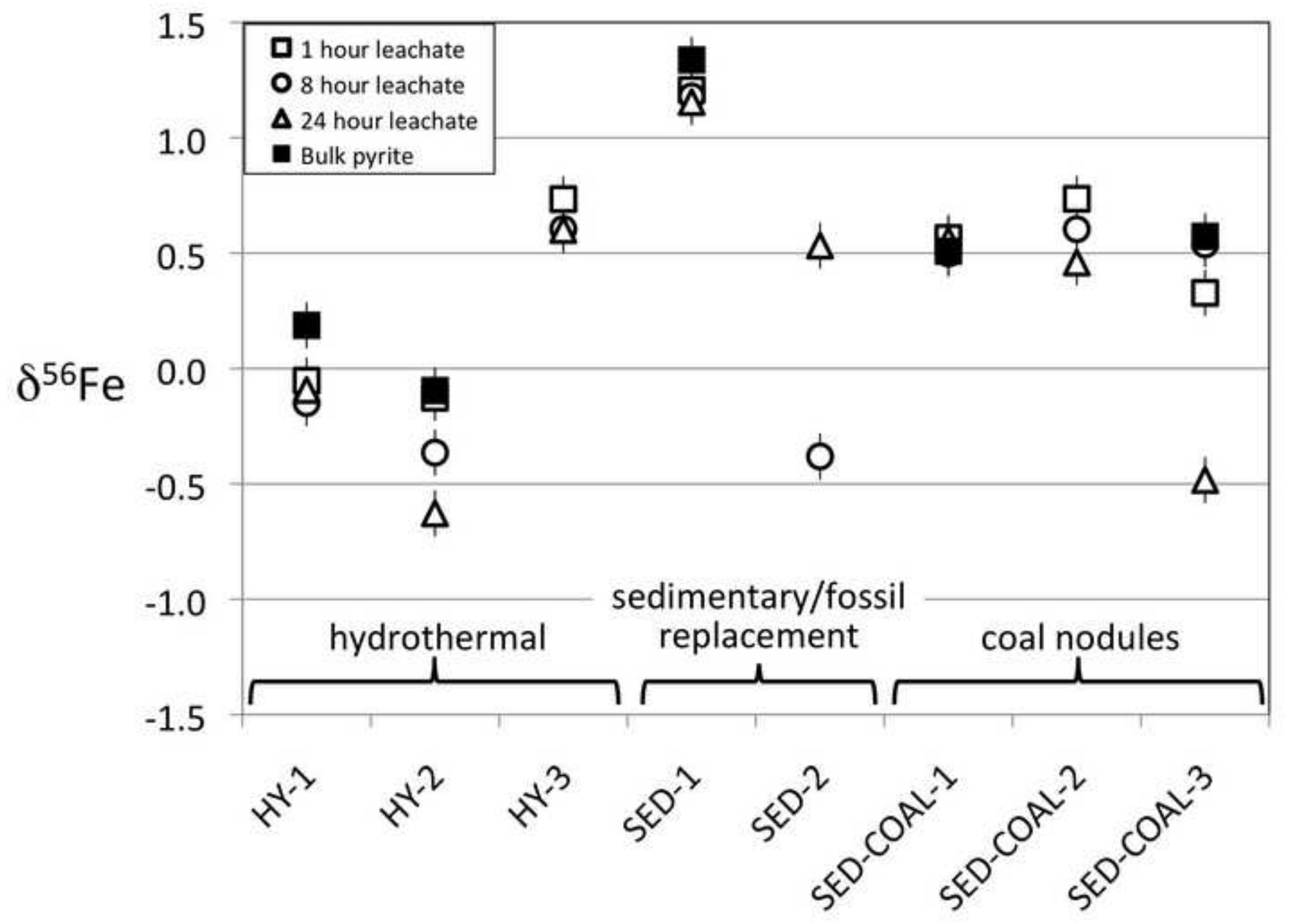




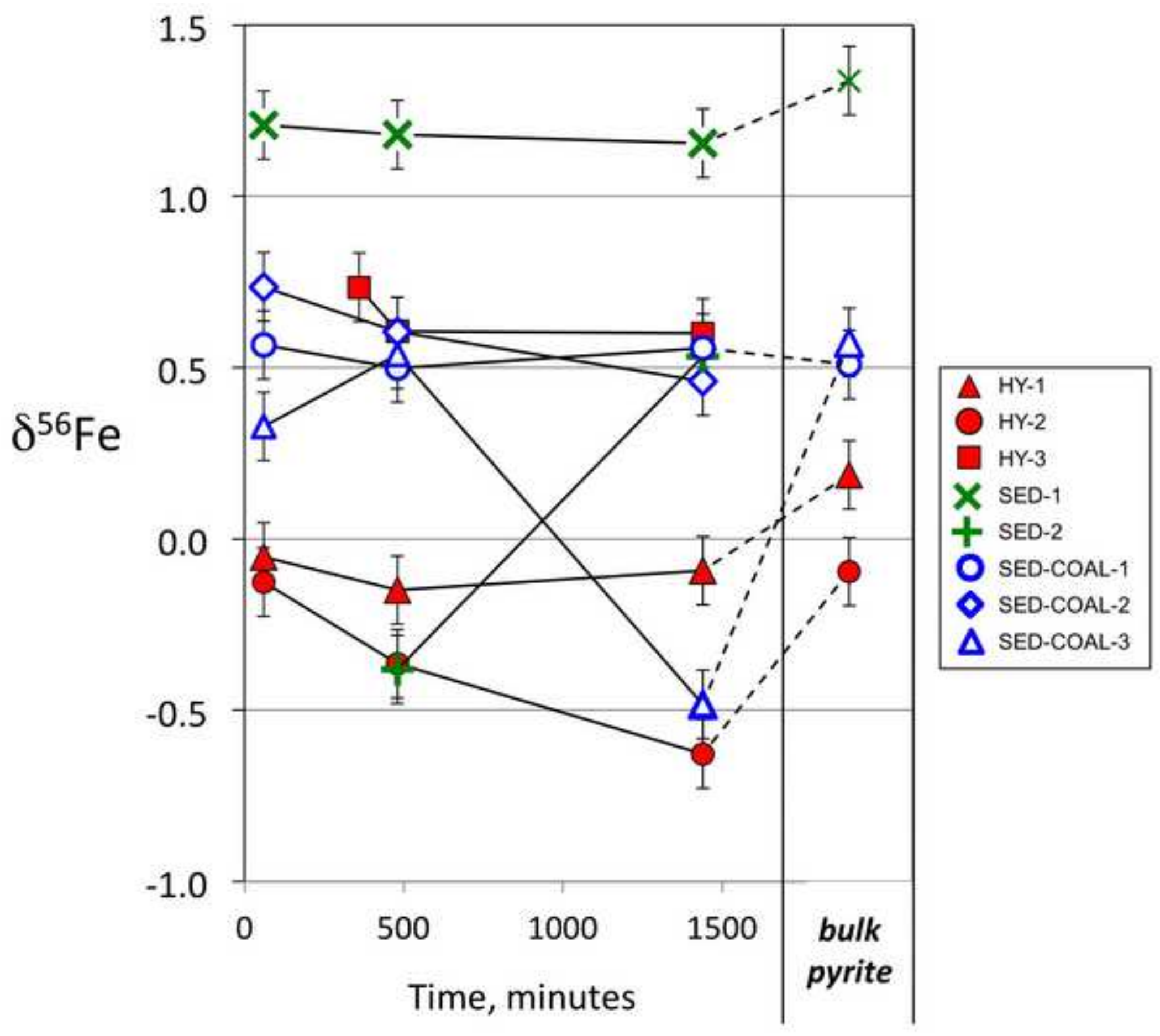




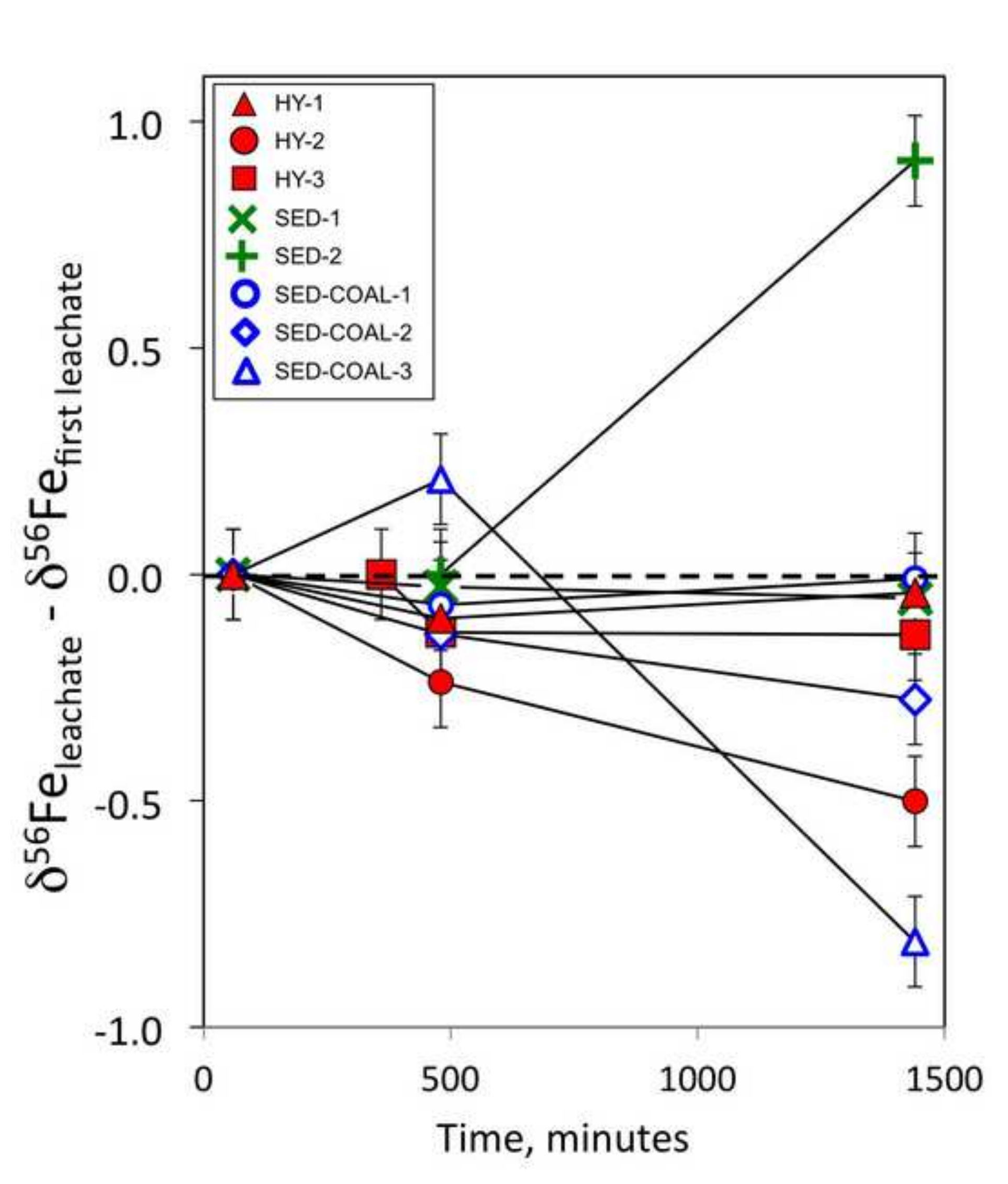

Figure 7

\section{7}

\section{Figure

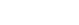 \\ Figu}

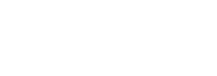

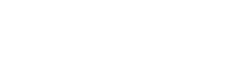




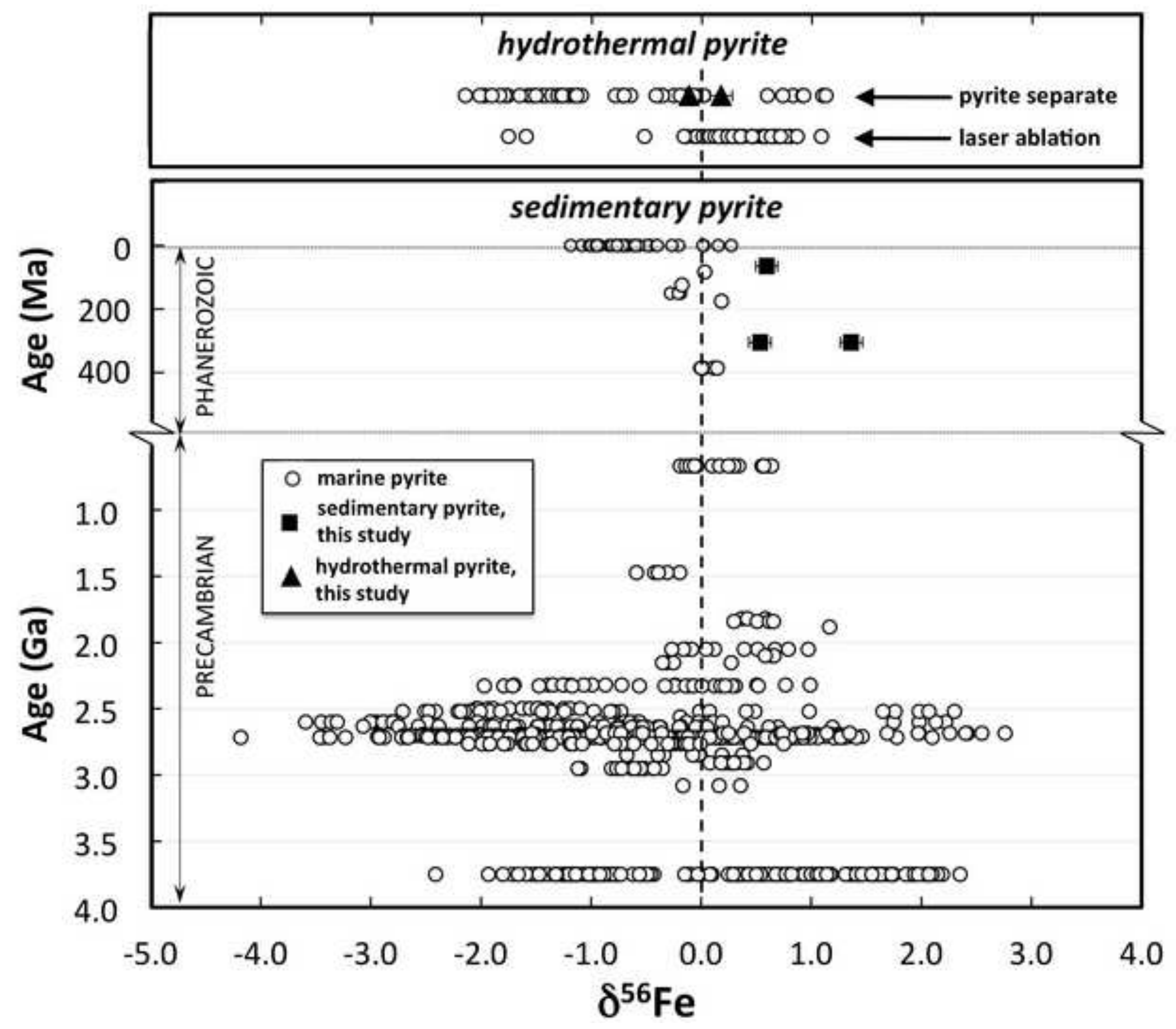


Table 1. Characteristics of pyrite samples used in this study. Mineralogy was confirmed using x-ray diffraction.

\begin{tabular}{|c|c|c|c|c|c|c|}
\hline Sample ID & Source/Location & Morphology & Petrogenetic Environment & Mineralogy & $\begin{array}{c}\mathrm{S} / \mathrm{Fe}^{\mathrm{a}} \\
\text { (molar) }\end{array}$ & $\begin{array}{c}\text { Specific } \\
\text { Surface Area }^{\mathrm{b}} \\
\left(\mathrm{m}^{2} / \mathrm{g}\right)\end{array}$ \\
\hline $\mathrm{HY}-1$ & Hubbard Scientific & Nodular & Hydrothermal & Pyrite & 2.01 & 0.22 \\
\hline $\mathrm{HY}-2$ & Peru & Nodular & Hydrothermal & Pyrite & 2.02 & 0.10 \\
\hline HY-3 & Spain & Nodular & Hydrothermal & Pyrite & 2.03 & 0.07 \\
\hline SED-1 & Illinois, USA & $\begin{array}{l}\text { Nodular, } \\
\text { pyrite sun }\end{array}$ & $\begin{array}{l}\text { Sedimentary, within bedding } \\
\text { planes of shale }\end{array}$ & Pyrite & 2.02 & 0.35 \\
\hline SED-2 & $\begin{array}{l}\text { New Albany Shale; } \\
\text { Indiana, USA }\end{array}$ & Nodular & Sedimentary; fossil replacement & Pyrite & 2.04 & 0.21 \\
\hline SED-COAL-1 & Pennsylvania, USA & Nodular & Sedimentary, within coal & Pyrite & 2.02 & 2.82 \\
\hline SED-COAL-2 & Texas, USA & Nodular & Sedimentary, within coal & $\begin{array}{l}\text { Pyrite with } \\
\text { minor quartz }\end{array}$ & 1.97 & 0.42 \\
\hline SED-COAL-3 & Texas, USA & Nodular & Sedimentary, within coal & Pyrite & 1.97 & 5.37 \\
\hline
\end{tabular}

${ }^{a} \mathrm{~S} / \mathrm{Fe}$ determined by ICP-AES on total sample digestion.

${ }^{\mathrm{b}} \mathrm{Specific}$ surface area measured by nitrogen adsorption multipoint BET method (ISO 2010). 
Table 2. Trace element concentrations $(\mu \mathrm{g} / \mathrm{g})$ in bulk pyrite samples. Where indicated, minimum $(>)$ and maximum $(<)$ values fell outside the limits of quantification by ICP-MS.

trace element concentration, $\mu \mathrm{g} / \mathrm{g}$

\begin{tabular}{|c|c|c|c|c|c|c|c|c|c|c|c|c|c|c|c|c|c|c|c|c|}
\hline Element & $\mathrm{Ag}$ & As & Al & $\mathrm{Au}$ & $\mathrm{Ba}$ & $\mathrm{Bi}$ & $\mathrm{Br}$ & $\mathrm{Ca}$ & Cd & Co & $\mathrm{Cr}$ & Cs & $\mathrm{Cu}$ & Ga & $\mathrm{Ge}$ & $\mathrm{Hf}$ & $\mathrm{Hg}$ & K & In & $\mathrm{Li}$ \\
\hline Detection Limit & 0.2 & 0.03 & 2 & 0.002 & 0.1 & 0.3 & 3 & 700 & 0.01 & 0.005 & 0.5 & 0.001 & 0.2 & 0.01 & 0.01 & 0.001 & 0.2 & 30 & 0.001 & 1 \\
\hline HY-1 & 0.6 & $>25$ & 23 & 0.003 & 0.0 & 17.7 & 3 & 602 & 0.03 & $>25$ & 0.9 & 0.041 & $>25$ & 0.13 & 0.16 & 0.003 & $<0.2$ & 6 & 0.128 & $<1$ \\
\hline HY-2 & 0.7 & 20.14 & 31 & 0.001 & 0.1 & 10.6 & 4 & 149 & 0.11 & 14.330 & 0.3 & 0.002 & $>27$ & 0.12 & 0.41 & 0.001 & 0.0 & 20 & 0.223 & $<1$ \\
\hline HY-3 & 0.2 & 4.43 & $>313$ & 0.007 & 0.5 & 19.4 & 4 & 1816 & 0.07 & $>31$ & 5.9 & 0.044 & $>31$ & 0.77 & 0.47 & 0.074 & 0.0 & 49 & 0.003 & $<1$ \\
\hline SED-1 & 2.0 & $>64$ & 259 & 0.001 & 4.2 & $<0.3$ & 8 & 289 & 0.38 & 7.924 & 5.8 & 0.076 & $>64$ & 0.54 & 0.69 & 0.042 & 0.3 & 199 & 0.001 & $<1$ \\
\hline SED-2 & $<0.2$ & 32.15 & 401 & 0.004 & 20.5 & $<0.3$ & 24 & 2569 & 0.08 & 13.375 & 2.3 & 0.202 & $>177$ & 0.67 & 1.27 & 0.019 & $<0.2$ & 434 & 0.001 & $<1$ \\
\hline SED-COAL-1 & $<0.2$ & $>54$ & 305 & $<0.002$ & 8.3 & $<0.3$ & 8 & 189 & 0.35 & 0.250 & 1.4 & 0.311 & $>54$ & 0.16 & 0.24 & 0.029 & 3.1 & 132 & 0.007 & $<1$ \\
\hline SED-COAL-2 & 0.1 & $>53$ & 531 & 0.001 & 23.9 & $<0.3$ & 6 & 398 & 0.08 & 12.633 & 10.8 & 0.441 & $>53$ & 1.79 & 0.60 & 0.176 & 3.3 & 870 & 0.019 & 7.17 \\
\hline SED-COAL-3 & $<0.2$ & $>49$ & 276 & $<0.002$ & 4.0 & $<0.3$ & 6 & 197 & 0.26 & 0.708 & 0.7 & 0.107 & $>49$ & 0.14 & 0.29 & 0.021 & 8.6 & 79 & 0.005 & $<1$ \\
\hline
\end{tabular}

trace element concentration, $\mu g / g$ (continued)

\begin{tabular}{|c|c|c|c|c|c|c|c|c|c|c|c|c|c|c|c|c|c|c|c|c|}
\hline Element & $\mathbf{M g}$ & Mn & Mo & $\mathrm{Na}$ & $\mathrm{Nb}$ & $\mathrm{Ni}$ & $\mathrm{Pb}$ & $\mathbf{R b}$ & Re & $\mathbf{R u}$ & $\mathrm{Sb}$ & $\mathrm{Se}$ & Si & Sn & $\mathrm{Sr}$ & Ta & $\mathrm{Te}$ & Th & $\mathrm{Ti}$ & $\mathrm{TI}$ \\
\hline Detection Limit & 1 & 0.1 & 0.1 & 5 & 0.005 & 0.3 & 0.01 & 0.005 & 0.001 & 0.01 & 0.01 & 0.2 & 200 & 0.1 & 0.04 & 0.001 & 0.1 & 0.001 & 0.1 & 0.001 \\
\hline HY-1 & 134 & 103.6 & 0.7 & 12 & 0.009 & 69.6 & 4.10 & 0.028 & 0.021 & 0.11 & 0.36 & $>31$ & $<25$ & 0.6 & 0.37 & 0.001 & 18.9 & 0.073 & 0.7 & 0.006 \\
\hline HY-2 & 46 & 0.3 & 0.1 & 6 & 0.024 & 4.2 & 19.06 & 0.089 & 0.002 & 0.00 & 1.14 & 12.0 & $<27$ & $>11$ & 0.41 & 0.019 & 13.8 & 0.006 & 0.4 & 0.006 \\
\hline HY-3 & 576 & 27.6 & 0.1 & 13 & 0.118 & $>157$ & 17.07 & 0.246 & 0.000 & 0.05 & 0.44 & 22.5 & 251 & 0.5 & 0.92 & 0.013 & 1.3 & 2.693 & 39.9 & 0.011 \\
\hline SED-1 & 43 & 3.8 & 33.7 & 68 & 0.017 & 75.1 & $>64$ & 0.937 & 0.019 & 0.01 & 11.97 & 76.4 & 257 & 0.3 & 0.64 & 0.004 & $<0.1$ & 0.209 & 8.7 & $>6.4$ \\
\hline SED-2 & 284 & 132.9 & 13.2 & 201 & 0.032 & 179.8 & 12.49 & 1.754 & 0.003 & 0.03 & 0.25 & 13.1 & 354 & 0.2 & 6.09 & 0.011 & 0.1 & 0.098 & 3.5 & 1.41 \\
\hline SED-COAL-1 & 22 & 1.2 & 24.9 & 118 & 0.027 & 1.3 & 8.43 & 1.021 & 0.001 & 0.00 & 0.02 & 8.4 & 108 & 2.4 & 2.12 & 0.002 & $<0.1$ & 0.443 & 15.0 & $>5.4$ \\
\hline SED-COAL-2 & 2545 & 56.8 & 3.9 & 67 & 0.133 & 69.8 & 19.98 & 3.875 & $<0.001$ & 0.00 & 1.06 & $>66$ & 451 & 0.2 & 5.39 & 0.005 & $<0.1$ & 3.238 & 67.9 & $>5.3$ \\
\hline SED-COAL-3 & 14 & 3.1 & 14.5 & 89 & 0.014 & 1.8 & 15.47 & 0.518 & $<0.001$ & 0.01 & 0.41 & 8.0 & 99 & 1.2 & 2.12 & 0.003 & $<0.1$ & 0.104 & 4.4 & $>4.9$ \\
\hline
\end{tabular}

\begin{tabular}{|c|c|c|c|c|c|c|c|c|c|c|c|c|c|c|c|c|c|c|c|c|}
\hline \multirow[b]{2}{*}{ Element } & \multicolumn{6}{|c|}{ trace element concentration, $\mu g / g$ (continued) } & \multicolumn{14}{|c|}{ rare earth element concentration, $\mu \mathrm{g} / \mathrm{g}$} \\
\hline & $\mathbf{u}$ & v & w & $\mathbf{Y}$ & $\mathrm{Zn}$ & $\mathrm{Zr}$ & La & $\mathrm{Ce}$ & $\operatorname{Pr}$ & Nd & Sm & $\mathrm{Eu}$ & Gd & $\mathrm{Tb}$ & Dy & Ho & Er & $\mathrm{Tm}$ & $\mathrm{Yb}$ & Lu \\
\hline Detection Limit & 0.001 & 0.1 & 0.02 & 0.003 & 0.5 & 0.01 & 0.001 & 0.001 & 0.001 & 0.001 & 0.001 & 0.001 & 0.001 & 0.001 & 0.001 & 0.001 & 0.001 & 0.001 & 0.001 & 0.001 \\
\hline HY-1 & 0.317 & 0.5 & $>2.5$ & 0.399 & 12.1 & 0.10 & 0.198 & 0.658 & 0.111 & 0.449 & 0.068 & 0.028 & 0.074 & 0.010 & 0.054 & 0.011 & 0.034 & 0.005 & 0.036 & 0.005 \\
\hline HY-2 & 0.319 & $>6.8$ & $>2.7$ & 0.036 & $>34$ & 0.02 & 0.007 & 0.026 & 0.003 & 0.019 & 0.009 & 0.002 & 0.010 & 0.002 & 0.009 & 0.002 & 0.005 & 0.001 & 0.005 & 0.001 \\
\hline HY-3 & 0.366 & 2.7 & $>3.1$ & 1.185 & 26.1 & 2.43 & 0.302 & 0.709 & 0.095 & 0.437 & 0.236 & 0.105 & 0.344 & 0.054 & 0.276 & 0.048 & 0.132 & 0.019 & 0.140 & 0.018 \\
\hline SED-1 & 0.236 & 4.7 & $>6.4$ & 0.172 & 18.8 & 1.70 & 0.104 & 0.227 & 0.026 & 0.096 & 0.021 & 0.004 & 0.021 & 0.003 & 0.023 & 0.006 & 0.021 & 0.004 & 0.032 & 0.006 \\
\hline SED-2 & 0.044 & 2.0 & $>18$ & 0.315 & 64.7 & 0.71 & 0.187 & 0.407 & 0.055 & 0.221 & 0.057 & 0.014 & 0.059 & 0.009 & 0.049 & 0.009 & 0.023 & 0.004 & 0.022 & 0.004 \\
\hline SED-COAL-1 & 0.032 & 0.8 & 2.37 & 0.411 & 15.4 & 0.80 & 0.711 & 1.818 & 0.202 & 0.792 & 0.157 & 0.028 & 0.135 & 0.017 & 0.075 & 0.012 & 0.035 & 0.004 & 0.027 & 0.004 \\
\hline SED-COAL-2 & 0.525 & 11.4 & $>5.3$ & 2.471 & 38.0 & 5.49 & 6.263 & 13.057 & 1.505 & 5.547 & 1.075 & 0.255 & 1.016 & 0.128 & 0.581 & 0.096 & 0.268 & 0.033 & 0.225 & 0.031 \\
\hline SED-COAL-3 & 0.020 & 0.5 & $>4.9$ & 0.226 & 23.0 & 0.67 & 0.077 & 0.243 & 0.023 & 0.103 & 0.028 & 0.007 & 0.037 & 0.006 & 0.033 & 0.007 & 0.020 & 0.003 & 0.017 & $\begin{array}{c}0.00 \\
3\end{array}$ \\
\hline
\end{tabular}


Table 3. Dissolved Fe and S concentrations in leachate collected during pyrite dissolution experiments at $\mathrm{pH}=3$.

\begin{tabular}{|c|c|c|c|c|}
\hline Sample ID & $\begin{array}{l}\text { Sampling } \\
\text { time (min.) }\end{array}$ & $\begin{array}{c}\mathrm{Fe} \\
(\mu \mathrm{M})\end{array}$ & $\underset{(\mu M)}{S}$ & $\begin{array}{c}\text { Molar } \\
\text { S/Fe }\end{array}$ \\
\hline \multirow[t]{3}{*}{$\mathrm{HY}-1$} & 60 & 9.7 & 6.5 & 0.67 \\
\hline & 480 & 23.0 & 27.8 & 1.21 \\
\hline & 1440 & 54.5 & 78.2 & 1.43 \\
\hline \multirow[t]{3}{*}{ HY-2 } & 60 & 10.2 & 7.1 & 0.69 \\
\hline & 480 & 15.8 & 16.4 & 1.04 \\
\hline & 1440 & 35.7 & 48.2 & 1.35 \\
\hline \multirow[t]{3}{*}{ HY-3 } & 360 & 10.1 & 14.4 & 1.43 \\
\hline & 480 & 11.5 & 14.3 & 1.24 \\
\hline & 1440 & 28.1 & 42.9 & 1.53 \\
\hline \multirow[t]{3}{*}{ SED-1 } & 60 & 10.2 & 7.4 & 0.72 \\
\hline & 480 & 24.3 & 25.6 & 1.05 \\
\hline & 1440 & 59.8 & 79.9 & 1.34 \\
\hline \multirow[t]{3}{*}{ SED-2 } & 60 & 8.6 & 7.0 & 0.81 \\
\hline & 480 & 20.2 & 29.0 & 1.44 \\
\hline & 1440 & 52.1 & 84.8 & 1.63 \\
\hline \multirow[t]{3}{*}{ SED-COAL-1 } & 60 & 56.1 & 72.3 & 1.29 \\
\hline & 480 & 157.0 & 259.0 & 1.65 \\
\hline & 1440 & 427.0 & 828.0 & 1.94 \\
\hline \multirow[t]{3}{*}{ SED-COAL-2 } & 60 & 22.2 & 26.1 & 1.18 \\
\hline & 480 & 71.4 & 108.0 & 1.51 \\
\hline & 1440 & 220.0 & 400.0 & 1.82 \\
\hline \multirow[t]{3}{*}{ SED-COAL-3 } & 60 & 38.3 & 64.8 & 1.69 \\
\hline & 480 & 161.0 & 287.0 & 1.78 \\
\hline & 1440 & 477.0 & 807.0 & 1.69 \\
\hline
\end{tabular}


Table 4. Speciation calculation results for S (top) and Fe (bottom) in the pyrite dissolution experiments using Visual MINTEQ.

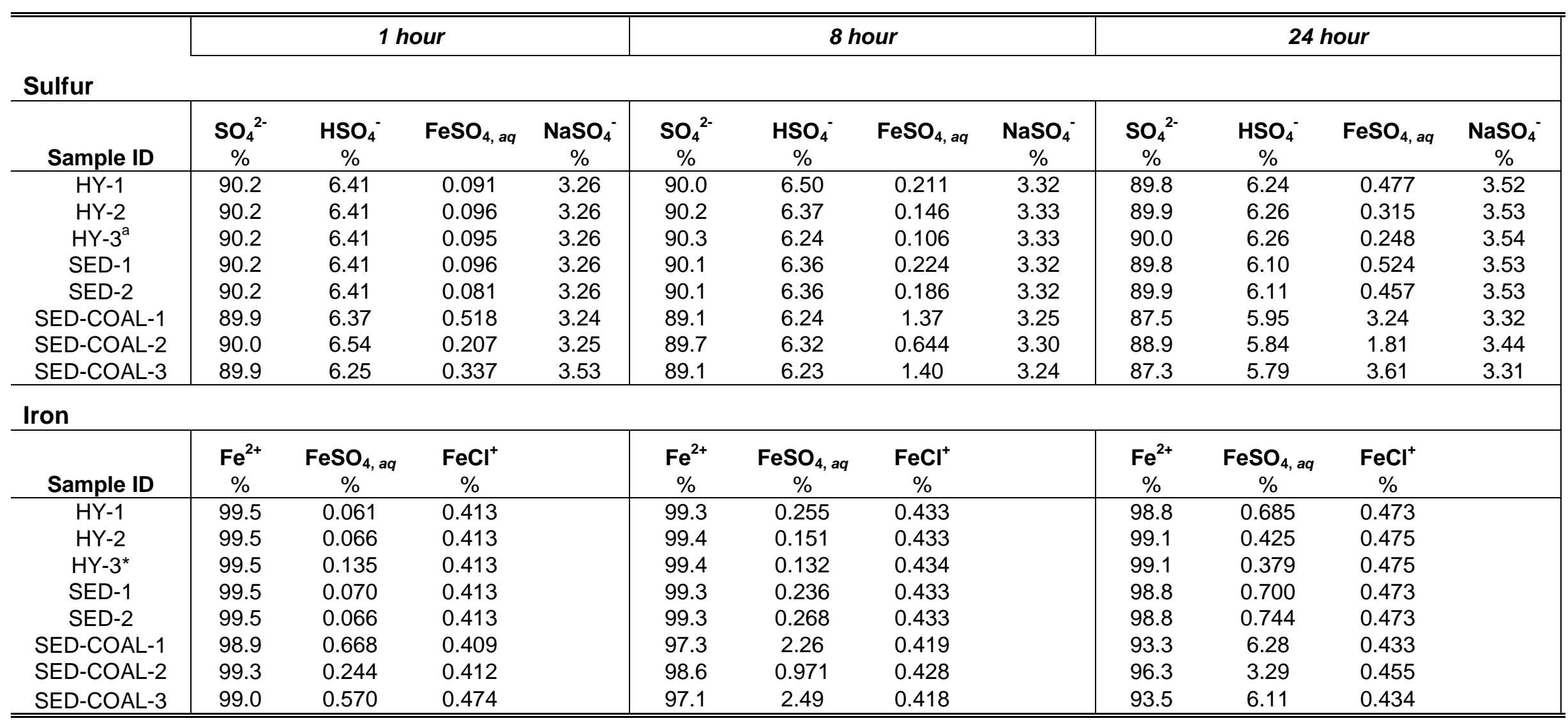

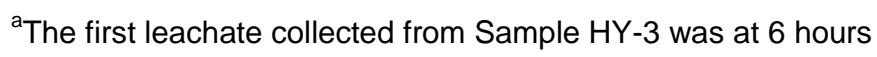


Table 5. Iron isotope data for bulk pyrite samples and dissolved Fe sampled during pyrite oxidative dissolution experiments conducted at $\mathrm{pH}=3$ (relative to standard IRRM-14).

\begin{tabular}{|l|c|c|c|c|c|}
\hline \multirow{2}{*}{ Sample } & \multicolumn{5}{|c|}{$\delta^{56} \mathrm{Fe}^{\mathrm{a}}$} \\
\cline { 2 - 6 } & \multirow{2}{*}{$\begin{array}{c}\text { Bulk } \\
\text { Pyrite }\end{array}$} & \multicolumn{3}{|c|}{ dissolution experiment leachates } \\
\cline { 3 - 6 } & $\mathbf{1 ~ h r}$. & $\mathbf{6} \mathbf{~ h r}$. & $\mathbf{8} \mathbf{~ h r}$. & $\mathbf{2 4} \mathbf{~ h r}$. \\
\hline HY-1 & 0.19 & -0.05 & & -0.15 & -0.09 \\
HY-2 & -0.10 & -0.13 & & -0.36 & -0.63 \\
HY-3 & & & 0.73 & 0.61 & 0.60 \\
\hline SED-1 & 1.34 & 1.21 & & 1.18 & 1.15 \\
SED-2 & & & & -0.38 & 0.53 \\
\hline SED-COAL-1 & 0.51 & 0.57 & & 0.50 & 0.56 \\
SED-COAL-2 & & 0.74 & & 0.60 & 0.46 \\
SED-COAL-3 & 0.57 & 0.33 & & 0.54 & -0.48 \\
\hline
\end{tabular}

${ }^{\mathrm{a}}$ Measurement uncertainty $(2 \sigma)$ for all reported values is $\pm 0.1 \%$. 